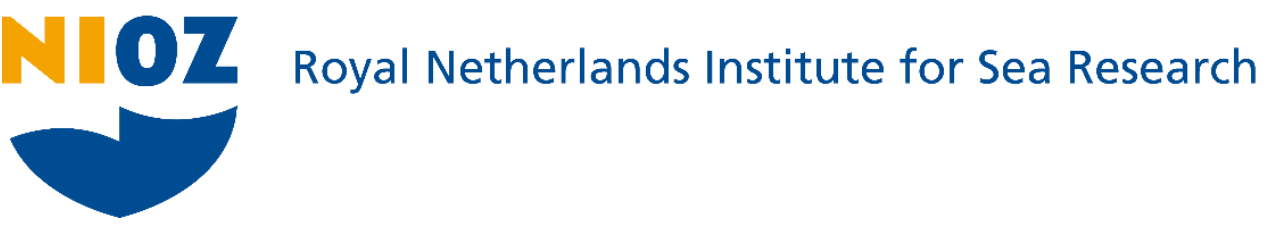

This is a postprint of:

Van der Molen, J.; Ruardij, P. \& Greenwood, N. (2017). A 3D SPM model for biogeochemical modelling, with application to the northwest European continental shelf. Journal of Sea Research, 127, 63-81

Published version: https://dx.doi.org/10.1016/j.seares.2016.12.003

Link NIOZ Repository: www.vliz.be/nl/imis?module=ref\&refid=289069

[Article begins on next page]

The NIOZ Repository gives free access to the digital collection of the work of the Royal Netherlands Institute for Sea Research. This archive is managed according to the principles of the Open Access Movement, and the Open Archive Initiative. Each publication should be cited to its original source - please use the reference as presented.

When using parts of, or whole publications in your own work, permission from the author(s) or copyright holder(s) is always needed. 
1

6

7

\section{A 3D SPM model for biogeochemical modelling, with application to the northwest European continental shelf}

\author{
Johan van der Molen ${ }^{* 1}$, Piet Ruardij², Naomi Greenwood ${ }^{1,3}$
}

*Corresponding author

${ }^{1}$ The Centre for Environment, Fisheries and Aquaculture Science (Cefas), Pakefield Road, Lowestoft, Suffolk NR33 OHT, UK; Tel.: +44 (0) 150252 7768, fax: +44 (0) 1502 513865, e-mail: johan.vandermolen@cefas.co.uk

${ }^{2}$ Royal Netherlands Institute for Sea Research (NIOZ), P.O. Box 59, 1790 AB Den Burg (Texel), The Netherlands; Tel.: (+31) (0)222-369300, fax: (+31) (0)222-319674, e-mail: rua@nioz.nl

${ }^{3}$ School of Environmental Sciences, University of East Anglia, Norwich Research Park, Norwich, Norfolk NR4 7TJ, UK 


\section{Abstract}

19 An SPM resuspension method was developed for use in 3D coupled hydrodynamicsbiogeochemistry models to feed into simulations of the under-water light climate and and primary production. The method uses a single mineral fine SPM component for computational efficiency, with a concentration-dependent settling velocity to parameterize the effect of settling of different size fractions. The SPM is resuspended in response to combined wave and current conditions. Wave conditions were calculated using a simple set of equilibrium equations, which allows computationally cheap inclusion of the large-scale spatial and temporal trends of the wave field. The development was carried out using 1D water-column implementations of GOTMERSEM-BFM for two sites for which multi-year time series observations from autonomous moorings (SmartBuoy) were available. A sensitivity study is included to illustrate the effect of the main variables controlling the exchange with the sea-bed and the settling velocity. The method was applied to a 3D model implementation of GETM-ERSEM-BFM for the north-west European continental shelf, comparing mineral fine SPM concentrations at five sites with SmartBuoy observations, and shelfwide using remote sensing. The 3D implementation included a simple fitting method to generate gridded sea-bed composition information for use in the sea-bed boundary conditions. The results showed that the model produces reasonable simulations of seasonal SPM concentrations across the northwest European continental shelf. 


\section{Introduction}

\subsection{Background}

Suspended (mineral) particulate matter (SPM) can contribute significantly to the turbidity of coastal seas, and as such modify the attenuation of sun light penetrating from the surface through scattering and absorption. Because phytoplankton require light to grow, SPM can constitute a significant modulating factor for primary production and associated nutrient cycling. Hence, the effects of SPM on the underwater light climate are usually included in biogeochemical models used in the coastal ocean, in addition to contributions by clear water, coloured disolved organic matter (CDOM) and phytoplankton self shading (Jerlov, 1976; Baker and Lavelle, 1984; Campbell and Spinrad, 1987; Gallegos and Correll, 1990; Apel, 1995; Bowers et al., 2004). These other three factors are fairly well understood, and relatively easily included in biogeochemical models, and will not be further discussed here. Because SPM models can be computationally expensive additions to already expensive biogeochemical models and SPM concentrations are notoriously difficult to model, the current implementations of SPM in biogeochemical models tend to contain significant simplifications. These could be i) climatologies based on observations (ECOHAM4, Lenhart et al., 2010) ii) climatologies based on monthly satellite composites (MICRO\&COHERENCE-3D, Lenhart et al., 2010), iii) a relaxation to weekly satellite composites (POLCOMS-ERSEM, Lenhart et al., 2010), iv) a combination of monthly satellite composites and a current-based SPM model (ECOMARS3D, Lenhart et al., 2010), v) a current-based SPM transport model (WESCH3D, Xu and Hood, 2006; Delft3D-GEM, Lenhart et al., 2010; Van Kessel et al., 2011; ROMS, Feng et al., 2015) or vi) proportionalities with local wave-induced bedshear stress (GETM-ERSEM-BFM, Lenhart et al., 2010; Van der Molen et al., 2014). As biogeochemical models are increasingly in demand for what-if scenarios in coastal seas to address questions relating to eutrophication, renewable energy generation, climate change and carbon and nutrient budgets and cycling, a good representation of dynamic, water-column resolved SPM concentrations in response to changes in forcing associated with the scenarios in question is becoming increasingly important. This can only be achieved with a model.

In an earlier study using 1D water column models in combination with high temporal resolution time series of SPM concentrations in coastal waters, Van der Molen et al. (2009) showed that inclusion of both current and wave effects on resuspension is necessary to simulate SPM concentrations. Moreover, they demonstrated that, because of their different settling velocities, a range of size fractions (at least four) is needed to to simulate SPM concentrations both in high temporal detail, and over seasonal cycles. As separate size fractions need to be advected separately in 3D models, and spatial advection constitutes the main computational cost for state variables in 3D models (four additional state variables would consume approximately $10 \%$ of the compute time in ERSEM-BFM; moreover if a sand fraction were included explicitly the model time step would have to be reduced), limiting the computational burden of an SPM model leaves more compute time for biological processes in any particular application. Hence, here, we here present and investigate the implementation of a variant of the method of Van der Molen et al. (2009) in 1D and 3D biogeochemical models using a single SPM fraction, but with a parameterization to adjust the settling velocity to the instantaneous SPM concentration based on the assumption that the average grain size (and hence settling velocity) at high concentrations is larger than at low 
concentrations. As it contains only a single advected state variable, the method is computationally as cheap as it can be made, while containing continuous (rather than discrete) size-dependent settling, and giving a reasonable simulation of SPM concentrations induced by a combination of currents and waves in a wide range of hydrodynamic conditions including seasonal and riverine stratification. For the remainder of this paper, SPM is defined as fine, mineral material (clay and silt). At this stage, the model contains a static bottom SPM pool, and hence-only conserves the mass while material issediment that has been suspended, and does not track deposited sediment, for a number of reasons. Firstly, the primary aim was to improve the light climate calculations, making a good representation of SPM concentrations in the upper water column the most important criterium. Earlier experience with a much simpler implementation relating SPM concentrations directly to the bed-shear stress suggested this a viable approach (Van der Molen et al., 2014). Secondly, not including a dynamic bottom pool imposes a useful control on the SPM model: concentrations in the fixed bottom pool will remain at 'observed' levels, ensuring that the SPM model will continue to perform in the same way throughout the simulations to provide concentrations for the light calculation. Making this dynamic would enable the bottom pool to diverge from 'observed' levels as material is washed away or accumulated. If such changes in the bottom SPM pool were unrealistic, eg. through an accumulation of inaccuracies in the hydrodynamics and SPM calculations, they would over time lead to reduced performance in terms of the desired light climate calculations. It was decided that adding a dynamic, mass-conservative bottom pool was better left for a next stage of work. A limitation of assuming a static bottom pool is that the model can not self-adjust deviations in the bottom pool, and has limited ability to carry SPM across areas with low concentrations in the bottom pool.

An application that clearly demonstrates the utility of this method in a biogeochemical context by identifying an SPM-dominated response mechanism can be found in a study of the potential environmental effects of tidal energy generation by Van der Molen et al. (2016).

\subsection{Study area}

The shelf to the west and north of the UK (Figure 1) is typically one to several hundreds of km wide, and has a depth of 100-200 m, in contrast to the North Atlantic Ocean to the west, which reaches depths of several thousands of $m$. The Celtic and Irish Seas separate Ireland from the mainland of the UK, and the English Channel separates the UK from the continent in the south. The North Sea to the east, between the UK and the European continent, has typical depths of over $100 \mathrm{~m}$ in the north, and less than $50 \mathrm{~m}$ in the south. The North-west European shelf, and in particular the North and Irish Seas, support a high biological production, but are at the same time used heavily for a range of economic activities including shipping, fishing, oil and gas extraction, pipe lines, and aggregate extraction, while also containing a large number of marine protected areas of various types (see, e.g., Paramor et al., 2009, OSPAR, 2010). 


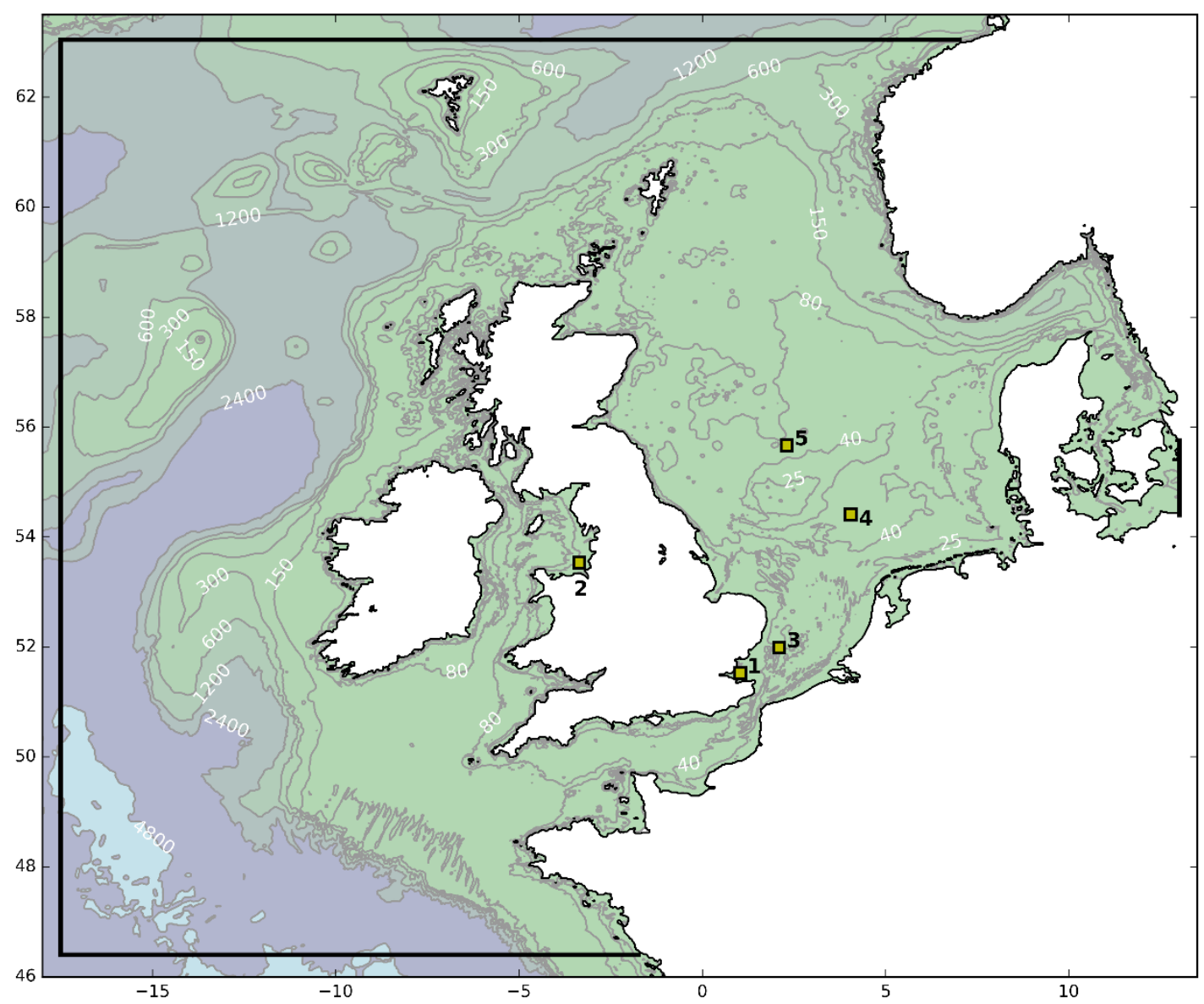

Figure 1. The north-west European continental shelf, with 3D model area (thick line) and SmartBuoy stations (yellow squares; 1: Warp Anchorage, 2: Liverpool Bay, 3: West Gabbard, 4: Oyster Grounds, 5: North Dogger ). Depth contours in m.

On the shelf, the tides interact with the topography, wave climate and river runoff to create a range of stratification and mixing conditions (Pingree et al., 1978; van Leeuwen et al., 2015), and sea bed disturbance, sediment resuspension and transport mechanisms (e.g., van der Molen, 2002; Aldridge et al., 2015). The shelf seas support a high level of primary productivity, which, during the last decades, has been augmented by varying and gradually reducing levels of anthropogenic riverine nutrient loads, and which depends on local SPM concentrations that affect the availability of light (e.g., Lenhart et al., 2010). Current- and wave-induced SPM concentrations on the northwest European continental shelf display a high level of spatial and temporal variability, in particular in more shallow waters, as is becoming increasingly evident from satellite observations (e.g., Eleveld et al., 2008; Dobrynin et al., 2010).

For five sites (Figure 1), time-series observations of SPM from SmartBuoy (Greenwood et al., 2010) were available. Site 1, Warp Anchorage, is situated in wellmixed conditions at $15 \mathrm{~m}$ water depth in a channel in the Thames Estuary. Site 2, Liverpool Bay, was situated in intermittently stratified, river-influenced conditions (e.g., Verspecht et al., 2009) at $23 \mathrm{~m}$ water depth in the eastern Irish Sea, and formed part of the Liverpool Bay Coastal Observatory (http://cobs.pol.ac.uk/cobs). Site 3, West Gabbard, is situated in well-mixed conditions in $32 \mathrm{~m}$ water depth in the southern bight of the North Sea. Site 4, Oyster Grounds, was situated in mostly seasonally stratified waters in $45 \mathrm{~m}$ water depth. Site 5 , North Dogger, was situated in 
seasonally stratified waters in $80 \mathrm{~m}$ water depth. Sea bed composition varies between the sites, with West Gabbard and Liverpool Bay having coarser sand beds (355 and $250 \mu \mathrm{m})$, and Warp Anchorage, Oyster Grounds and North Dogger having finer beds $(125,1 \mathrm{E} 2$ and $1 \mathrm{E} 2 \mu \mathrm{m})$. Sites 4 and 5 were studied extensively as part of the Marine Ecosystem Connections programme (see Painting and Foster, 2013 and references therein).

\section{Methods}

\subsection{SmartBuoy observations}

Time series of near-surface optical back scatter were obtained from a routine monitoring programme at the Warp Anchorage (2002-present), Liverpool Bay (2001present), the West Gabbard (2002-present), Oyster Grounds (2006-2013) and North Dogger (2007-2008) sites using SmartBuoy (Mills et al., 2003; Greenwood et al., 2010; www.cefas.defra.gov.uk/monitoring; see Figure 1 for locations). The buoy consists of a $1.9 \mathrm{~m}$ wide toroidal float with a purpose built stainless steel frame for mounting instruments below surface. The payload includes, among others, an OBS sensor (OBS, Seapoint Sensors, Inc., New Hampshire, USA), of which the results were used here, has a manufacturer-specified linear response up to concentrations of $500 \mathrm{mg} \mathrm{l}^{-1}$. For a detailed study of the response of the sensor, see Green et al. (1999). A Cefas purpose built solid state logger (ESM2) samples each sensor at $1 \mathrm{~Hz}$ for two 10 -minute bursts each hour. A burst average is calculated from quality-assured data. The quality assurance procedure includes, among others, rejection of data from periods when bio-fouling is suspected. An automated water sampler (Aqua Monitor, EnviroTech, Virginia, USA) is used for collection and storage of up to 50 water samples of $150 \mathrm{ml}$ each for subsequent gravimetric analysis of SPM. In general 2-3 water samples are collected at pre-set times for each week of deployment using this method. Sensors and the water sampler are held at fixed depths between 1 and $2 \mathrm{~m}$. The optical back scatter readings from SmartBuoy were calibrated using SPM observations from a combination of water samples collected in situ by the on-board water sampler of SmartBuoy and samples collected in situ using a ship-based rosette sampler (see Van der Molen et al., 2009 for some further detail).

\subsection{Satellite observations}

Daily fields of satellite observations of non-algal suspended matter from the MODIS satellite (modis.gsfc.nasa.gov) were obtained from the Ifremer ftp server (ftp.ifremer.fr.:/ifremer/cersat/products/gridded/ocean-color/atlantic), processed as described by Gohin (2005) and Gohin (2011). Time series were extracted for comparison with SmartBuoy observations and model results at the SmartBuoy sites. Six-monthly composites were constructed for the periods October 2007 to March 2008 (winter), and April 2008 to September 2008 (growing season/summer) by interpolating to the model grid, and averaging the available data at each grid position. Growing season and winter periods were separated because of their different hydrographic characteristics and different biogeochemical function. We chose to present 6-month averages both to obtain a reasonable amount of cloud-free conditions, and to limit the amount of results for presentation purposes. For comparison, the model results were sub-sampled to coincide with the daily satellite data. The sub-sampled model results were also averaged, and bias and correlation coefficients with the satellite data were computed for each grid cell. The results were plotted as maps to obtain a shelf-wide impression of the model's performance. The 
time periods were chosen to summarise a full year, and illustrate the main seasonal changes within the year (growing season, temperature stratification period), with a minimum number of maps.

\subsection{Hydrodynamics and biogeochemistry models}

The SPM model developed here was included in the biogeochemistry model ERSEMBFM (European Regional Seas Ecosystem Model - Biogeochemical Flux Model), and coupled to the 1D water column hydrodynamics model GOTM (General Ocean Turbulence Model) for development and testing, and the 3D hydrodynamics model GETM (General Estuarine Transport Model) for realistic applications.

\subsubsection{ERSEM-BFM}

The ERSEM-BFM (European Regional Seas Ecosystem Model - Biogeochemical Flux Model) version used here (19-02-2015) is a development of the model ERSEM III (see Baretta et al., 1995; Ruardij and Van Raaphorst, 1995; Ruardij et al., 1997; Vichi et al., 2003; Vichi et al., 2004; Ruardij et al., 2005; Vichi et al., 2007; Van der Molen et al., 2013; van der Molen et al., 2014; www.nioz.nl/northsea_model), and describes the dynamics of the biogeochemical fluxes within the pelagic and benthic environment. The ERSEM-BFM model simulates the cycles of carbon, nitrogen, phosphorus, silicate and oxygen and allows for variable internal nutrient ratios inside organisms, based on external availability and physiological status. The model applies a functional group approach and contains five pelagic phytoplankton groups, four main zooplankton groups and five benthic faunal groups, the latter comprising four macro-fauna and one meio-fauna groups. The SPM model described here was implemented as an additional state variable in ERSEM-BFM. For an application including biogeochemistry with the current model see Van der Molen et al. (2016).

\subsubsection{GOTM}

GOTM (General Ocean Turbulence Model) is a public domain, one-dimensional Finite Difference hydrodynamical water column model designed initially for testing turbulence closure models (Burchard et al., 1999; www.gotm.net). It solves the 1DV partial differential equations for conservation of mass, momentum, salt and heat. It is forced by sea-surface elevations, meteorological conditions and depth-averaged tidal currents. Existing setups for the Oyster Grounds (Van der Molen et al, 2013) and the West Gabbard (Van der Molen et al., 2009) SmartBuoy sites were used (see Figure 1 for locations).

\subsubsection{GETM}

The 3D hydrodynamic model GETM (General Estuarine Transport Model, www.getm.eu; Burchard \& Bolding, 2002) solves the shallow-water, heat balance and density equations. It uses GOTM to solve the vertical dimension. For the current work, GETM was run on a spherical grid covering the area $46.4^{\circ} \mathrm{N}-63^{\circ} \mathrm{N}, 17.25^{\circ} \mathrm{W}$ $13^{\circ} \mathrm{E}$ with a resolution of $0.02^{\circ}$ longitude and $0.05^{\circ}$ latitude (approximately $5 \mathrm{~km}$ ), and 25 non-equidistant layers in the vertical. The model bathymetry was based on the NOOS bathymetry (www.noos.cc/index.php?id=173). The model was forced with tidal constituents derived from TOPEX-POSEIDON satellite altimetry (LeProvost et al., 1998), atmospheric forcing from the ECMWF ERA-40 and Operational Reanalysis (ECMWF, 2006a,b), interpolated river runoff and nutrients from a range of observational data sets (the National River Flow Archive 
260 (www.ceh.ac.uk/data/nrfa/index.html) for UK rivers, the Agence de l'eau Loire261 Bretagne, Agence de l'eau Seine-Normandie and IFREMER for French rivers, the 262 DONAR database for Netherlands rivers, ARGE Elbe, the Niedersächsisches 263 Landesamt für Ökologie and the Bundesanstalt für Gewässerkunde for German rivers, 264 and the Institute for Marine Research, Bergen, for Norwegian rivers; see also Lenhart et al., 2010). SPM inputs from rivers or coastal erosion were not included. Depthresolved temperature- and salinity boundary conditions from derived from ECMWORAS4 model results (Balmaseda et al., 2013; Mogensen et al., 2012).

\subsection{SPM Model}

The main structure of the SPM model follows that of Van der Molen et al. (2009). The SPM is assumed to be of purely mineral, inorganic origin, and contained within a sea bed consisting mainly of non-cohesive sand. Only the SPM within the active layer of sand (i.e. that which can be set in motion) is available for resuspension. Only the resuspended SPM fraction, and not the sand, is simulated within the water column, based on the assumption that events energetic enough to lead to significant sand concentrations in surface waters are rare during the growing season. Hence the mobilisation calculations are for the sand matrix to release the SPM, but the advection, diffusion and settling calculations consider only the SPM fraction. The resuspension is governed by combined currents and waves following Soulsby (1997). The settling of SPM is governed by a concentration-dependent settling velocity governed by a power law, based on the assumption that higher SPM concentrations contain increased contributions of coarser fractions and thus settle faster. Eomesive processes such as flocelation ean be considered to be included in this settling mechism, becense they also be represent by a pow law for the settling

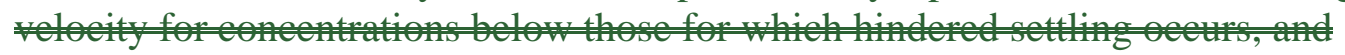

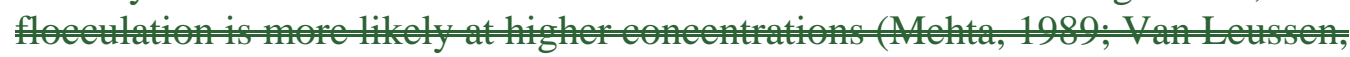

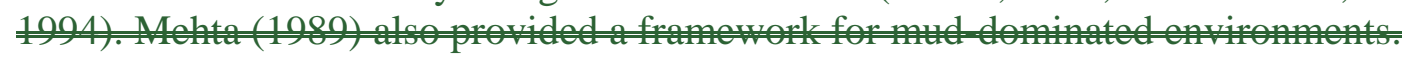
Voulganis and Meyers (2004) provide detaile overie and in-situ obserations of

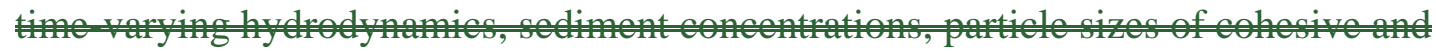
non-chesive frations, and settling velocities in a tidal enek, including diseussion of relationships be size and settling velocity. Salinity an influence both floceulation and potentially settling velocities (eg. Pontela et al., 2013), but such pesestion and excretion of mineral SPM by pelagic biota may also play a role, but was not included, nor was hindered settling. The detailed parameterisations used here are presented below. Other ap hes for spatially solved SPM molling ascible. For instanee,

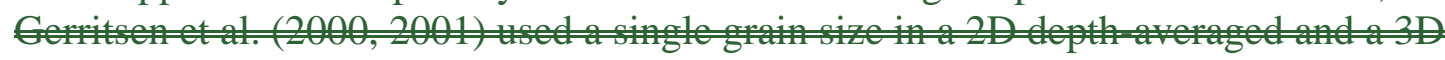
app w an sion fommation an rivine, sea bed som tems alibrated though a fitting proedme in situ and remote sensing SPM data. Their 2D appore use a fixed, spatially dependent setting

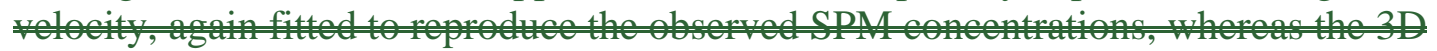
approach compared a fixed settling velocity with a power law formulation as used here, but to power 1 (i.e. linear in the oncentation). Gayer al., 2006 modelled SPM conentrans in the North Sea and Baltic Sea using three size fractions, a layed bed with an orosion-depth parameterisation related to the shear velocity and within bed diffusion relat to biotubation. They included clifferiosion and fluvial sources, and a sea bed composition map based on combination of multiplesources

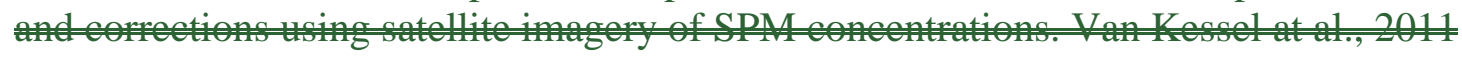
\#se grainsizes and a sea bed buffer mpo of a sandlayer and a fluff layer, 
eombined with an erosion appach, and tened to asingle SmantBey timeseries (Noordij). Ralston al. (2012) considered four size frations, and studied the

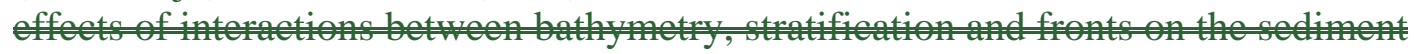
dymamies in an estuay. They found, among others, trapping of sedimentby fronts and

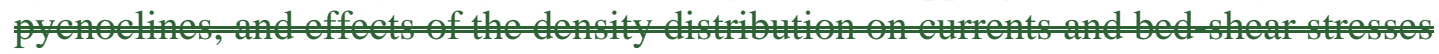
which affected erosion and deposition.

\subsubsection{Wave calculations}

As GETM-ERSEM-BFM does not contain a wave model, and coupling a state-of-theart wave model would be computationally expensive for the multi-decadal computations often required for biogeochemical models, a simplified approach was used that was developed based mostly on observations in the North Sea in the 1960's and 70's (see Van Rijn, 1994). A variation of this approach has been used successfully to capture the main large-scale spatial and temporal features of the wave climate in the North Sea in the past (Van der Molen and De Swart, 2001; Van der Molen, 2002). Significant wave height $H_{s}[\mathrm{~m}]$ and peak period $T_{p}$ [s] were calculated using the Sverdrup-Munk-Bretschneider (SMB) method (Shore Protection Manual, 1984) for deep water as described by Van Rijn (1994), assuming duration limitation. A depthlimitation was applied for shallow water to represent reductions in wave height by surf-zone processes:

$$
H_{s}=\max \left(H_{s, \text { deep }}, 0.4 h\right)
$$

with $h[\mathrm{~m}]$ the local water depth. The deep-water significant wave height $H_{\text {s,deep }}[\mathrm{m}]$ is given by:

$$
H_{s, \text { deep }}=\min \left(H_{s, \text { deep }, \text { full }}, H_{s, \text { deep }, \text { lim }}\right)
$$

with $H_{s, \text { deep,full }}[\mathrm{m}]$ and $H_{s, \text { deep,lim }}[\mathrm{m}]$ the fully developed and wind-event durationlimited wave heights, respectively:

$$
\begin{gathered}
H_{s, \text { deep,full }}=0.243 \frac{U^{2}}{g} \\
H_{s, \text { deep,lim }}=0.0016 \sqrt{F_{*}} \frac{U^{2}}{g}
\end{gathered}
$$

Here, $g=9.81 \mathrm{~ms}^{-2}$ is the gravitational acceleration, $U=0.7 W^{1.2}\left[\mathrm{~ms}^{-1}\right]$ the adjusted wind speed with $W\left[\mathrm{~ms}^{-1}\right]$ the wind speed at $10 \mathrm{~m}$ above the sea surface, and

$$
\boldsymbol{F}_{*}=\frac{g F}{U^{2}}
$$

the dimensionless fetch [-], with $F=W t_{d}$ [m] the fetch. The wave growth duration $t_{d}$ [s] was set to $t_{d, \max }=10800 \mathrm{~s}(3 \mathrm{hr})$, which gave reasonable SPM predictions at the West Gabbard and Oystergrounds locations. As the method is intended for application on the entire shelf, no detailed tuning was attempted for this particular location. For water depths less than $10 \mathrm{~m}$, where the coast, sand banks or tidal flats are likely to be near and limiting the fetch, the wave growth duration was scaled quadratically with depth: 


$$
t_{d}=\left(\frac{h}{10}\right)^{2} t_{d, \max }
$$

This quadratic formulation gave better results for the Warp Anchorage location than a linear formulation. Alternatively, a more general power law could be considered using the power as a fitting parameter for a particular location.

In similarity to the wave height, the wave peak period [s] was calculated as:

$$
T_{p}=\max \left(1, \min \left(T_{p, f u l l}, T_{p, l i m}\right)\right)
$$

with

$$
\begin{gathered}
T_{p, f u l l}=8.14 \frac{U}{g} \\
T_{p, \text { lim }}=0.286 F_{*}^{0.33} \frac{U}{g}
\end{gathered}
$$

These formulations could be improved by considering the 'true' wind duration and fetch (Van der Molen and De Swart, 2001; Van der Molen 2002). More accurate wave predictions could be obtained by coupling a time- and space resolving wavepropagation model, but at considerable cost.

Finally, for input in the SPM calculation, near-bed wave-orbital velocities uorb $\left._{\text {[ms }}{ }^{-1}\right]$ were calculated using linear wave theory, which assumes constant density and surface pressure, incompressibility, inviscidness, negligible surface tension, a horizontal, impermeable bed, and monochromatic waves:

$$
u_{o r b}=\left|\frac{\pi H_{s}}{T_{p} \sinh \frac{2 \pi h}{L}}\right|
$$

where wave length $L[\mathrm{~m}]$ follows from iteratively solving the dispersion relation. The near-bed wave-orbital excursion was given by:

$$
A_{w}=\frac{u_{o r b} T_{z}}{2 \pi}
$$

\subsubsection{Threshold of motion}

The critical shear stress for the initiation of motion of the sand matrix of the bed within which the SPM is contained, $\tau_{c r}\left[\mathrm{Nm}^{-2}\right]$ was calculated from the threshold Shields parameter $\theta_{c r}$ [-] (Shields, 1936) as:

$$
\tau_{c r}=\theta_{c r} g\left(\rho_{s}-\rho\right) D
$$

with $\rho$ and $\rho_{s}\left[\mathrm{kgm}^{-3}\right]$ the density of water and sediment, respectively, and $D=250$ $\mu \mathrm{m}$ the grain size of the sand fraction, taken here to be spatially uniform. The threshold Shields parameter was calculated following Soulsby and Whitehouse (1997) as

$$
\theta_{c r}=\frac{c_{6}}{1+c_{9} D_{*}}+c_{7}\left(1-e^{-c_{8} D_{*}}\right)
$$


439

with $c_{6}=0.3, c_{7}=0.055, c_{8}=0.02$, and $c_{9}=1.2$ empirical constants [Soulsby, 1997], and $\mathrm{D} *$ the non-dimensional grain size:

$$
D_{*}=D\left[\frac{g\left(\frac{\rho_{s}}{\rho}-1\right)}{\nu^{2}}\right]^{\frac{1}{3}}
$$

with $v\left[\mathrm{~m}^{2} \mathrm{~s}^{-1}\right]$ the kinematic viscosity calculated as a function of temperature as [Van Rijn, 1994]

$$
v=v_{r} \frac{2}{1+\frac{T}{T_{r}}}
$$

with $v_{r}=1.0 \mathrm{E}-6 \mathrm{~m}^{2} \mathrm{~s}^{-1}$ the kinematic viscosity at reference temperature $T_{r}=20{ }^{\circ} \mathrm{C}$, and $T$ $\left[{ }^{\circ} \mathrm{C}\right]$ temperature.

\subsubsection{Skin-friction bed-shear stress}

The combined (maximum) wave-current skin-friction bed-shear stress $\tau_{\max }$ was calculated using Soulsby's [1995, 1997] method which was based on a data fitting procedure:

$$
\begin{gathered}
\tau_{m}=\tau_{c}\left(1+c_{10}\left(\frac{\tau_{w}}{\tau_{c}+\tau_{w}}\right)^{c_{11}}\right) \\
\tau_{\text {max }}=\sqrt{\left(\tau_{m}+\tau_{w} \cos \phi_{w c}\right)^{2}+\left(\tau_{w} \sin \phi_{w c}\right)^{2}}
\end{gathered}
$$

where $\tau_{c}$ and $\tau_{w}\left[\mathrm{Nm}^{-2}\right]$ are the skin-friction bed-shear stresses due to currents and waves, respectively, $\tau_{m}\left[\mathrm{Nm}^{-2}\right]$ the mean wave-current skin friction shear stress, $\phi_{w c}$ [rad] is the angle between waves and currents, and $c_{10}=1.2$, and $c_{11}=3.2$ are empirical constants [Soulsby, 1997].

The skin-friction bed-shear stress due to currents was calculated using the law of wall, which assumes a logarithmic velocity profile zero velocity at the solid-fluid boundary, as

$$
\begin{gathered}
\tau_{c}=\rho_{w} u_{*}^{2} \\
\boldsymbol{u}_{*}=\frac{\mathrm{\kappa} U_{1}}{\ln \left(h_{1} / z_{0}\right)} \\
z_{0}=\frac{D}{12}
\end{gathered}
$$

where $z_{0}[\mathrm{~m}]$ the grain-related roughness length, $U_{1}\left[\mathrm{~ms}^{-1}\right]$ is the current velocity magnitude in the centre of the first grid cell above the bed at height $h_{1}[\mathrm{~m}], D[\mathrm{~m}]$ the grain size of the sand fraction, $\kappa=0.4$ von Kàrmàn's constant, $\rho_{w}\left[\mathrm{kgm}^{3}\right]$ the density of sea water, and index 1 refers to the centre of the first grid cell above the bed as before.

The grain-related skin-friction bed-shear stress due to waves was calculated following Soulsby [1997], assuming a flat bed at the grain-size scale

$$
\tau_{w}=\frac{1}{2} \rho_{w} f_{w} u_{o r b}^{2}
$$

$$
f_{w}=c_{13}\left(\frac{u_{o r b} T_{p}}{2 \pi z_{0}}\right)^{c_{14}}
$$


440

441

442

443

444

445

446

447

448

449

450

451

452

453

454

455

456

457

458

459

460

461

462

463

464

465

466

467

468

469

470

471

472

473

474

475

476

477

where $f_{w}[-]$ the wave-friction factor, and $c_{13}=1.39$ and $c_{14}=-0.52$ empirical constants [Soulsby, 1997].

\subsubsection{Sea-bed ripples}

Current ripple wave length $\lambda_{r c}[\mathrm{~m}]$ and height $\eta_{r c}[\mathrm{~m}]$ were calculated as (Soulsby, 1997):

$$
\begin{gathered}
\lambda_{r c}=\left\{\begin{array}{cc}
1000 D & \theta_{c}>\theta_{c r} \\
0 & \theta_{c} \leq \theta_{c r}
\end{array}\right. \\
\eta_{r c}=\frac{\lambda_{r c}}{14}
\end{gathered}
$$

where $\theta_{c}[-]$ is the skin-friction related shields parameter for currents, calculated in analogy to (10) using the skin-friction current shear stress $\tau_{c}\left[\mathrm{Nm}^{-2}\right]$. The value of the denominator in the calculation of $\eta_{r c}$ was set twice as large as reported by (Soulsby, 1997), as this value gave better SPM concentration predictions under tide-dominated conditions.

Wave ripple height $\eta_{r w}[\mathrm{~m}]$ and length $\lambda_{r w}[\mathrm{~m}]$ were calculated following Grant and Madsen (1982) as reported by Soulsby (1997):

$$
\eta_{r w}=\left\{\begin{array}{cc}
0 & \theta_{w} \leq \theta_{c r} \\
0.22 A_{w}\left(\frac{\theta_{w}}{\theta_{c r}}\right)^{-0.16} & \theta_{c r}<\theta_{w} \leq \theta_{b} \\
0.48 A_{w}\left(\frac{D_{*}^{1.5}}{4}\right)^{0.8}\left(\frac{\theta_{w}}{\theta_{c r}}\right)^{-1.5} & \theta_{w}>\theta_{b}
\end{array}\right.
$$

$$
\lambda_{r w}=\left\{\begin{array}{cc}
0 & \theta_{w} \leq \theta_{c r} \\
\frac{\eta_{r w}}{0.16\left(\frac{\theta_{w}}{\theta_{c r}}\right)^{-0.04}} & \theta_{c r}<\theta_{w} \leq \theta_{b} \\
\frac{\eta_{r w}}{0.28\left(\frac{D_{*}^{1.5}}{4}\right)^{0.6}\left(\frac{\theta_{w}}{\theta_{c r}}\right)^{-1.0}} & \theta_{w}>\theta_{b}
\end{array}\right.
$$

with $\theta_{w}$ [-] the skin-friction related shields parameter for waves, calculated in analogy to (10) using the skin-friction wave shear stress $\tau_{w}\left[\mathrm{Nm}^{-2}\right]$, and

$$
\theta_{B}=1.8 \theta_{c r}\left(\frac{D_{*}^{1.5}}{4}\right)^{0.6}
$$

\subsubsection{Total bed-shear stress}

The total bed roughness zot $[\mathrm{m}]$ was calculated as

$$
z_{0 t}=z_{0}+z_{0 f}+z_{0 t r a n s}
$$

with zotrans [m] the transport-related roughness length, which becomes important at high flow velocities, following Wilson (1989)

$$
z_{0 \text { trans }}=\frac{5.0 \tau_{m}}{30.0 g\left(\rho_{s}-\rho\right)}
$$


and $z_{0 f}[\mathrm{~m}]$ the form-related roughness length induced by ripples calculated as

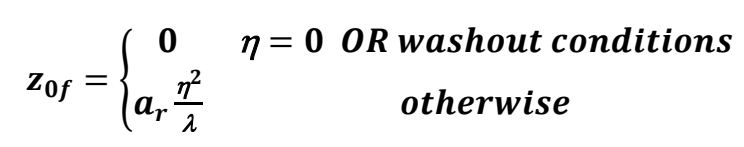

with $\eta=\max \left(\eta_{c}, \eta_{w}\right)[\mathrm{m}]$ and $\lambda[\mathrm{m}]$ the corresponding wave length, washout conditions (where waves and currents are so vigorous that ripples can not exist) defined as $\theta_{\max }>0.83$, and $\theta_{\max }$ [-] calculated in analogy to (10) using combined (maximum) wave-current skin-friction bed-shear stress $\tau_{\text {max. }}$.

The total current-shear stress $\tau_{c t o t}\left[\mathrm{Nm}^{-2}\right]$ was calculated from the law of wall (15), but using $\mathrm{z} 0 t$ instead of $\mathrm{zo}$. Similarly, the total wave-shear stress $\tau_{\text {wtot }}\left[\mathrm{Nm}^{-2}\right]$ was calculated from (16) while replacing $z o$ by $z o t$. Then, the total combined wave-current shear stress $\tau_{\text {maxtot }}\left[\mathrm{Nm}^{-2}\right]$ followed from (14), while using $\tau_{\text {ctot }}$ and $\tau_{\text {wtot. }}$.

\subsubsection{Reference height and concentration for the sand matrix} The reference level $z_{r e f}[\mathrm{~m}]$ and reference concentration $C_{r e f}\left[\mathrm{kgm}^{-3}\right]$ for the sand matrix were calculated following Smith and McLean (1977)

$$
\begin{gathered}
z_{r e f}=\frac{26.3 \tau_{c r} T_{s}}{\rho g\left(\frac{\rho_{s}}{\rho}-1\right) \frac{\rho_{s}}{\rho-1}}+z_{0} \\
C_{r e f}=\frac{0.00156 T_{s}}{1+0.0024 T_{s}}
\end{gathered}
$$

with $\mathrm{T}_{\mathrm{s}}$ the transport parameter

$$
T_{s}=\left\{\begin{array}{cc}
0 & \tau_{\text {maxtot }} \leq \boldsymbol{\tau}_{c r} \\
\frac{\tau_{\text {maxtot }}-\gamma_{c r}}{\tau_{c r}} & \tau_{\text {maxtot }}>\boldsymbol{\tau}_{c r}
\end{array}\right.
$$

With $\gamma=\{0,1\}$ a switch to include/exclude a threshold of motion. Van der Molen et al. (2009) found that not including the threshold of motion (i.e. $\gamma=0$ ) gave better results for sandy sites, so this was used here.

\subsubsection{Near-bed concentration for SPM fraction}

Under equilibrium conditions, the total amount of SPM in the water column cannot be greater than the amount of SPM available in the sea bed in the layer where the sand fraction gets disturbed by the hydrodynamics. To prevent unlimited SPM resuspension from the static bottom pool, a limiter was introduced for the reference concentration, assuming a maximum sea-bed disturbance depth of half the sea-bed ripple height (i.e. representing the volume of sand in the ripple field), and that, as a maximum, all available SPM within this disturbance depth is resuspended to form a uniform SPM concentration, (Van der Molen et al., 2009):

$$
C_{\text {ref,lim }}=\frac{F_{s} \rho_{s}}{h} \max \left(\frac{\eta}{2}, d_{\text {min }}\right)
$$

where $0 \leq F_{s} \leq 1$ the fraction of SPM in the sea bed, and $d_{\min }=0.01 \mathrm{~m}$ a minimum depth of disturbance and $h$ the local water depth. Under wash-out conditions, a substantial amount of sand can be resuspended in absence of ripples, and $\eta$ was given the value 
$0.15 \mathrm{~m}$ in (27). If conditions are vigorous enough to deplete the active layer of SPM, the water column is under-saturated in terms of SPM, and the available SPM can be expected to be distributed more evenly over the water column than in fully saturated conditions. Hence, the assumption of a flat concentration profile to limit the sea-bed boundary condition increases in validity as this limitation becomes stronger.

The SPM reference concentration was calculated as

$$
C_{r e f, S P M}=\min \left(F_{s} C_{r e f}, C_{r e f, l i m}\right)
$$

The corresponding concentration in the centre of the first grid cell at height $h_{1}[\mathrm{~m}]$ above the bottom was calculated assuming a Rouse profile, and using the reference level of the sand fraction that forms the matrix of the sea bed

$$
C_{1, S P M}=C_{r e f, S P M}\left(\frac{h_{1}\left(h-z_{r e f}\right)}{z_{r e f}\left(h-h_{1}\right)}\right)^{-b}
$$

These concentrations were used as sea-bed boundary conditions for 3D advection and diffusion of the SPM fraction using the advection-diffusion mechanisms of GETM, subject to the concentration-dependent settling velocities. The SPM fraction was implemented as a tracer within the ERSEM-BFM framework.

The formulation of the limiteris a coarse approximation, however can only be removed by including a sea-bed module and using the reference concentration to drive a diffusion mechanism for SPM pickup as done by Van der Molen et al. (2009).

\subsubsection{Concentration-dependent settling velocity for SPM}

Resuspended seabed material consists of a spectrum of grain sizes, which can be thought of as fractions, each with their own settling velocity that increases with grain size. A minimum number of size fractions are required in a model to obtain realistic concentrations in the water column (e.g., van der Molen et al.; 2009 suggested four). For simplicity, and to limit run times, we have assumed a single SPM class in the present model. Coarser fractions settle more quickly than finer ones, and more coarse material can be assumed to be present in higher-energy conditions resulting in higher SPM concentrations. Hence, we have assumed a concentration-dependent settling velocity for this single class, parameterised using a power law

$$
w_{s}=\min \left(a C^{b}, w_{s, \max }\right)
$$

with $C\left[\mathrm{kgm}^{3}\right]$ the SPM concentration in a particular grid cell in the model, and $a=0.15$ and $b=1.1$ fitting parameters that gave reasonable predictions of SPM concentrations in 1D water column models for the Oyster Grounds and the West Gabbard. A maximum settling velocity for SPM $w_{s, \max }=0.002 \mathrm{~ms}^{-1}$, equivalent to that of fine sand, was assumed to ensure computational stability.

Cohesive processes such as flocculation can be considered to be included in this settling mechanism, because they can also be represented by a power law for the settling velocity for concentrations below those for which hindered settling occurs, and flocculation is more likely at higher concentrations (Mehta, 1989; Van Leussen, 1994). Mehta (1989) also provided a framework for mud-dominated environments. Voulgaris and Meyers (2004) provide a detailed overview and in-situ observations of 
time-varying hydrodynamics, sediment concentrations, particle sizes of cohesive and non-cohesive fractions, and settling velocities in a tidal creek, including a discussion of relationships between size and settling velocity. Salinity can influence both flocculation and potentially settling velocities (eg. Portela et al., 2013), but such processes were not considered here.

\subsubsection{Stability mechanisms}

The methodology described above is sufficient for calculations for which a suitably small time step can be chosen. However, for shelf-sea applications which include very small water depths, and for calculations involving computationally intensive ecosystem models such as ERSEM-BFM, setting a suitably small time step is not compatible with achieving reasonable compute times. Hence, several controls were introduced to allow stable calculations:

- $w_{s, \max }$ was set to $0.002 \mathrm{~ms}^{-1}$; this had some, but not an overwhelming effect on the growing-season results (see sensitivity experiment 3 below);

- for water depths less than $5 \mathrm{~m}, w_{s, \max }$ was set to zero, effectively rendering SPM concentrations a purely diffusive process; as in these conditions the water column is generally well-mixed, and SPM concentrations limited by supply from the sea bed, this, in combination with a Dirichlet boundary condition where the concentration $C_{1, S P M}$ was applied to the diffusion step, did not affect the results very much. For water depths between 10 and $5 \mathrm{~m}, w_{s, \max }$ was ramped down linearly from 0.002 to $0 \mathrm{~ms}^{-1}$ to facilitate a transition zone. In shallow cells, this constraint is likely to lead to over-estimates in the SPM concentrations. However, for practical shelf-sea applications, there are not many grid cells to which this intervention applies (approximately 1\% of the wet grid cells for each of these depth ranges for the application presented here);

- for decreasing SPM concentrations in the lowest layer, the maximum decrease allowed was set to 0.4 times the value in the previous time step to prevent negative concentrations during occasional high-intensity settling; this condition only delayed the reduction in near-bed concentrations by a few time steps.

\subsection{Setups and experiments}

\subsubsection{D: GOTM with SPM}

The SPM model was developed and calibrated using model runs for the years 2006 and 2007 with the 1D GOTM setups for the Oyster Grounds and the West Gabbard, and the SmartBuoy SPM observations at these sites. Both setups used 40 layers in the vertical, and a time step of $300 \mathrm{~s}$. ERSEM-BFM takes porosity as an input variable for sea-bed composition (see also Section 2.5.3). Oyster Grounds was set to a water depth of $45 \mathrm{~m}$ and a sea-bed porosity of 0.424 , whereas West Gabbard was set to a water depth of $32 \mathrm{~m}$ and a porosity of 0.401 . Both these porosities corresponded to those applied at the same locations in the 3D model (Section 2.5.3). Each set up was forced with local tides derived from a 2D shelf model, and with local meteorology from the ECMWF operational analysis. All other parameter settings were the same.

After development and calibration using the years 2006-2007, a number of sensitivity experiments were carried out to investigate the influence of the parameters and 
618

619

620

621

622

623

624

625

626

627

628

629

630

631

632

633

634

635

636

637

638

639

640

641

642

643

644

645

646

647

648

649

650

651

parameterisations introduced in this study; i.e. those which were not taken from the literature on the results (Table 1).

Table 1. Parameters varied in sensitivity experiments

\begin{tabular}{|l|l|l|l|l|l|l|}
\hline Run & Sites & Period & $\begin{array}{l}\text { Variable/ } \\
\text { parameter }\end{array}$ & $\begin{array}{l}\text { Standard } \\
\text { value }\end{array}$ & $\begin{array}{l}\text { Sensitivity } \\
\text { Value }\end{array}$ & Equation \\
\hline $\mathbf{1}$ & $\begin{array}{l}\text { OG, } \\
\text { WG }\end{array}$ & $\begin{array}{l}2006- \\
2007\end{array}$ & $a$ & 0.15 & 0.3 & $(26)$ \\
\hline $\mathbf{2}$ & $\begin{array}{l}\text { OG, } \\
\text { WG }\end{array}$ & $\begin{array}{l}2006- \\
2007\end{array}$ & $b$ & 1.1 & 1.5 & $(26)$ \\
\hline $\mathbf{3}$ & $\begin{array}{l}\text { OG, } \\
\text { WG }\end{array}$ & $\begin{array}{l}2006- \\
2007\end{array}$ & $w_{s, \max }$ & $\begin{array}{l}0.002 \\
\mathrm{~ms}^{-1}\end{array}$ & $0.01 \mathrm{~ms}^{-1}$ & $(26)$ \\
\hline $\mathbf{4}$ & $\begin{array}{l}\text { OG, } \\
\text { WG }\end{array}$ & $\begin{array}{l}2006- \\
2007\end{array}$ & $\eta_{r c}$ & - & $* 2$ & $(17)$ \\
\hline $\mathbf{5}$ & $\begin{array}{l}\text { OG, } \\
\text { WG }\end{array}$ & $\begin{array}{l}2006- \\
2007\end{array}$ & $C_{r e f, l i m}$ & included & none & $(27),(28)$ \\
\hline $\mathbf{6}$ & WG & $\begin{array}{l}2006- \\
2007\end{array}$ & $t_{d, \max }$ & $\begin{array}{l}10800 \mathrm{~s} \\
(3 \mathrm{hr})\end{array}$ & $\begin{array}{l}21600 \mathrm{~s}(6 \\
\mathrm{hr})\end{array}$ & $\mathbf{( 5 )}$ \\
\hline $\mathbf{7}$ & $\begin{array}{l}\text { OG, } \\
\text { WG }\end{array}$ & $\begin{array}{l}2006- \\
2007\end{array}$ & $d_{\min }$ & $0.01 \mathrm{~m}$ & $0 \mathrm{~m}$ & $(27)$ \\
\hline
\end{tabular}

\subsubsection{D: GETM-ERSEM-BFM}

For realistic applications, a 3D model is more suitable than 1D water column models, which assume spatially homogeneous conditions unless forced specifically with lateral gradients (see Simpson et al., 2002). The coupled hydrodynamics-

biogeochemical model was run for three years: 2006-2008 (reference run). These years were chosen because of the availability of validation data. The spin-up period covered 2000-2005, with minor fixes to improve model stability of the benthic module applied in January 2004. The biogeochemistry state at the start of the spin-up period was taken from the end results of a run with an earlier, very similar model version covering 1995-2008. Model confirmation of this reference run consisted of a time-series comparison with SmartBuoy observations (Greenwood et al., 2010) at the 5 sites, representing different hydrographic conditions on the northwest European continental shelf.

\subsubsection{Sea-bed composition}

An important boundary condition for the SPM resuspension is the local SPM content of the sea bed. Because observations were not available for the whole model domain, a fitting procedure was developed to interpolate and extrapolate existing information, based on i) the North Sea Benthos Survey data (Basford et al., 1993) for clay and silt content, ii) the bathymetry (feeding into a wave parameterisation), and iii) tidal harmonics velocity amplitudes for neap-tide conditions $\left(\mathrm{M}_{2}-\mathrm{S}_{2}\right)$ from a separate run with the hydrodynamics model, and by assuming that the bed composition is more or less in equilibrium with the local hydrodynamic conditions. This calculation was carried out once to provide an input file for the model.

The fraction of silt and clay (SPM) content of the sea bed was assumed to be an exponential function of the square of the sum of an estimate of governing

hydrodynamical velocities: 


$$
F_{s}=a e^{-\lambda w}
$$

with $a$ and $\lambda$ fitting parameters, and $w$ a measure of the combined velocity:

$$
w=\left(u^{2}+v^{2}\right)+f_{w} u_{o r b}^{2}
$$

with $u$ and $v$ [ms $\left.{ }^{-1}\right]$ the longitudinal and latitudinal components of the neap-tidal current velocity amplitude, $f_{w}[-]$ a fitted wave-friction parameter, and $u_{o r b}\left[\mathrm{~ms}^{-1}\right]$ a wave-orbital velocity a form of (8) re-written in terms of the zero-crossing period $T_{z}$ [s]. The zero-crossing period $T_{z}$ and significant wave height $H_{s}$ were replaced with a governing wave period and height $T_{g}[\mathrm{~s}]$ and $H_{g}[\mathrm{~m}]$, respectively, which were assumed to be relevant for the distribution of SPM content, and estimated from the observations as part of the fitting procedure. The representative wave height was given by

$$
H_{g}=\max \left(H_{g, \min }, \min \left(H_{g, \max }, f_{b} h\right)\right)
$$

with $H_{g, \min }[\mathrm{m}]$ a fitted minimum wave height, $H_{g, \max }[\mathrm{m}]$ a fitted maximum wave height, $f_{b}$ a fitting parameter, and $h[\mathrm{~m}]$ local water depth.

A least-squares fitting procedure was applied, resulting in: $a=0.3121, \lambda=0.0007$, $H_{r, \min }=1.3621 \mathrm{~m}, H_{g, \max }=1.8533 \mathrm{~m}, T_{r}=14.7309 \mathrm{~s}, f_{b}=0.0223, f_{w}=2.0160$. The resulting function (Figure 2) was then applied to the model grid, compared with the North Sea Benthos Survey data (Figure 3), and used to prescribe the sea-bed composition in the model. The fit shows considerable scatter, but reproduced the main spatial trends in the observed values, but appears slightly 'stiff', i.e. missing the extremes. An iteration could be considered in which spatially resolved wave characteristics resulting from the simulations presented here are used to modify the fitting procedure. This may relax some of this stiffness.

Sea-bed porosity was calculated from the SPM content as

$$
\varepsilon=\varepsilon_{0}+c_{15} F_{s}
$$

with $\varepsilon_{0}=0.38662$ the porosity for a pure sand bed and $c_{15}=0.415$ an empirical constant. This relation was derived in unpublished work by Van Raaphorst and Ruardij.

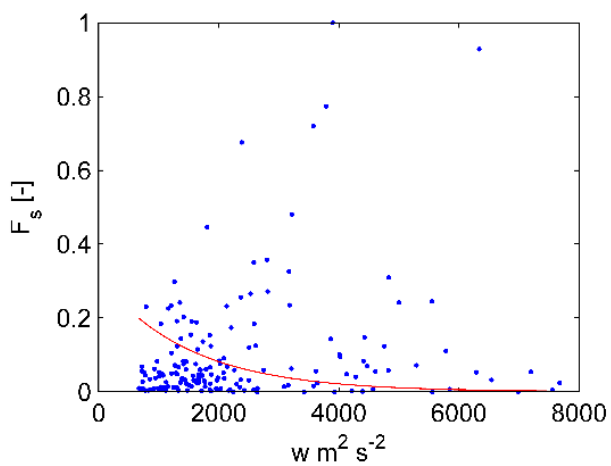

Figure 2. Fitted function (line) compared with observed SPM content (dots). 


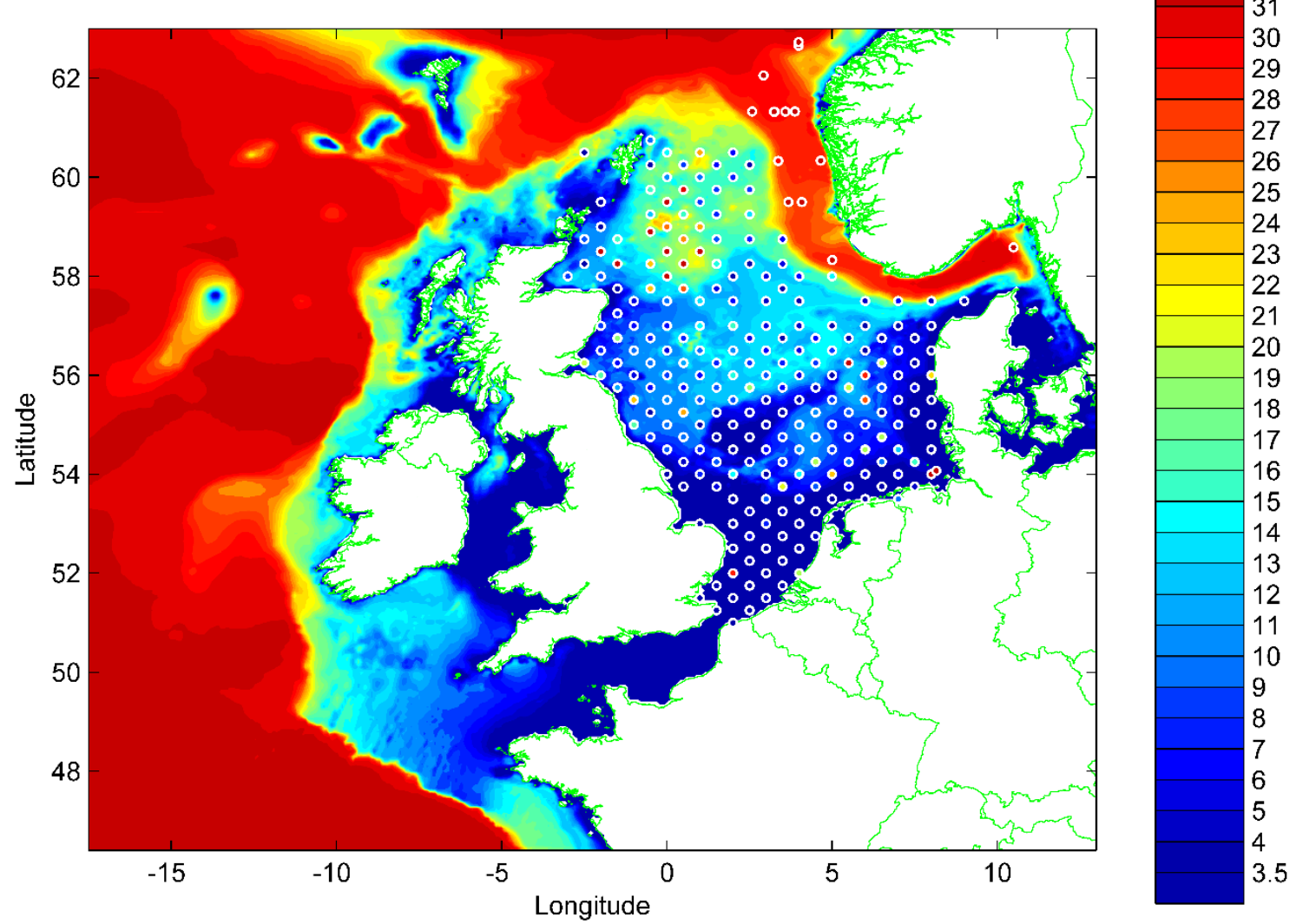

691

692

693

694

695

Figure 3. Comparison of the function-generated silt and clay (SPM) content [\%] of the sea bed with observations from the North Sea Benthos survey (Basford et al., 1993), circles.

Table 2. Results of sensitivity experiments

\begin{tabular}{|c|c|c|c|c|c|c|c|}
\hline Run & Site & Level & Variable & Sensitivity Value & $\begin{array}{c}\text { RMS } \\
{\left[\mathrm{mg} \mathrm{m}^{-3}\right]}\end{array}$ & Corr. & $\begin{array}{c}\text { Offset } \\
{\left[\mathrm{mg} \mathrm{m}^{-3}\right]}\end{array}$ \\
\hline & OG & surface & Reference & - & 2877.64 & 0.71 & 589.89 \\
\hline 1 & OG & surface & $a$ & 0.3 & 2680.65 & 0.66 & -65.21 \\
\hline 2 & OG & surface & $b$ & 1.5 & 7401.62 & 0.76 & 4939.07 \\
\hline 3 & OG & surface & $w_{s, \max }$ & $0.01 \mathrm{~ms}^{-1}$ & 1387.62 & 0.77 & -8.08 \\
\hline 4 & OG & surface & $\eta_{r c}$ & $* 2$ & 2877.64 & 0.71 & 589.89 \\
\hline 5 & OG & surface & $C_{\text {ref,lim }}$ & none & 89262.29 & 0.53 & 23204.18 \\
\hline 6 & OG & surface & $t_{d, \max }$ & 21600s (6 hr) & 5016.54 & 0.72 & 1951.02 \\
\hline \multirow[t]{2}{*}{7} & OG & surface & $d_{\min }$ & $0 \mathrm{~m}$ & 3138.12 & 0.59 & -613.49 \\
\hline & OG & $35 \mathrm{~m}$ & Reference & - & 4728.67 & 0.58 & 1270.58 \\
\hline 1 & OG & $35 \mathrm{~m}$ & $a$ & 0.3 & 4553.88 & 0.58 & 94.45 \\
\hline 2 & OG & $35 \mathrm{~m}$ & $b$ & 1.5 & 9380.02 & 0.56 & 8036.18 \\
\hline 3 & OG & $35 \mathrm{~m}$ & $w_{s, \max }$ & $0.01 \mathrm{~ms}^{-1}$ & 3864.16 & 0.54 & 607.89 \\
\hline 4 & OG & $35 \mathrm{~m}$ & $\eta_{r c}$ & $* 2$ & 4728.67 & 0.58 & 1270.58 \\
\hline 5 & OG & $35 \mathrm{~m}$ & $C_{\text {ref,lim }}$ & none & 142259.59 & 0.58 & 21678.77 \\
\hline 6 & OG & $35 \mathrm{~m}$ & $t_{d, \max }$ & 21600s (6 hr) & 11326.78 & 0.51 & 4399.98 \\
\hline \multirow[t]{2}{*}{7} & OG & $35 \mathrm{~m}$ & $d_{\min }$ & $0 \mathrm{~m}$ & 5092.4 & 0.57 & -1916.83 \\
\hline & WG & surface & Reference & & 6373.37 & 0.25 & -3618.58 \\
\hline 1 & WG & surface & $a$ & 0.3 & 7550.21 & 0.21 & -5394.01 \\
\hline 2 & WG & surface & $b$ & 1.5 & 7146.93 & 0.27 & 4419.53 \\
\hline 3 & WG & surface & $w_{s, \max }$ & $0.01 \mathrm{~ms}^{-1}$ & 6382.81 & 0.27 & -3780.30 \\
\hline
\end{tabular}


696

697

\begin{tabular}{|c|c|c|c|c|c|r|r|}
\hline $\mathbf{4}$ & WG & surface & $\eta_{r c}$ & $* 2$ & 6145.72 & 0.23 & -2952.16 \\
\hline $\mathbf{5}$ & WG & surface & $C_{r e f, l i m}$ & none & 55790.71 & 0.10 & 18719.85 \\
\hline $\mathbf{6}$ & WG & surface & $t_{d, \max }$ & $21600 \mathrm{~s}(6 \mathrm{hr})$ & 6714.12 & 0.24 & -2090.28 \\
\hline $\mathbf{7}$ & WG & surface & $d_{\min }$ & $0 \mathrm{~m}$ & 7186.78 & 0.16 & -4532.78 \\
\hline
\end{tabular}

\section{Results}

\subsection{D: GOTM with SPM}

Results of the calibrated SPM model (Figure 4) show reasonable agreement for concentrations at the surface and $35 \mathrm{~m}$ depth eoncentrations-for the Oyster Grounds (for statistics see text in figures and Table 2). The seasonal cycle reproduced well with no noticable difference in the timing of changes between summer and winter conditions, but individual winter resuspension events tended to be over-estimated by up to a factor of 3. To illustrate the contribion of the various processes to these SPM concentrations, the wave and current characteristics, bed-shear stresses, ripple heights and near-bed and near-surface settling velocities are given (Figure 5). The latter two illustrate the variability of the power law method both in time and through the water column. For the West Gabbard site, average summer concentrations were reproduced by the model, but with a stronger (2-3 times the amplitude) spring-neap cycle than in the observations. Winter concentrations were underestimated by up to a factor of 5 in 2006. Changing the parameters of the power law for the concentration-dependent settling velocity (26) resulted in lower concentrations (up to a factor of 2, in particular in summer) for an increase in $a$ to 0.3 (Run 1, Figure 6), and and higher concentrations (up to a factor of 3) for an increase in $b$ to 1.5 (Run 2, Figure 7) as may be expected. Increasing the maximum settling velocity $w_{s, \max }(26)$ to $0.01 \mathrm{~ms}^{-1}$ reduced the peak winter concentrations at the Oyster Grounds to values similar to those observed, but also further reduced the already under-estimated winter concentrations at the West Gabbard site (Run 3, Figure 8) to summer values. Doubling the current ripple height (17) to the literature value, Run 4, had no effect at the Oyster Grounds (Table 2), but increased the already over-estimated concentration differences over the spring-neap cycle at the West Gabbard site to 4-5 times the amplitude (Figure 9). Removing the limitation on resuspension (27), (28) resulted in a strong increase in winter concentrations to up to 100 times the observed values (Run 5, Figure 10, Table 2). Doubling the wave-event duration (5) increased peak concentrations at the Oyster Grounds by up to a factor of 2, but led to improvement of the winter concentrations at the West Gabbard, to around or exceeding observed values for 2007 and 2008, but still a factor of 2-3 below observed values for 2006 (Run 6, Figure 11). Finally, removing the minimum depth in the sediment from which resuspension can occur (27) resulted in near-zero concentrations under low wave conditions at the Oyster Grounds in summer and winter, and concentrations regularly approaching zero at neap tides at the West Gabbard site (Run 7, Figure 12). 

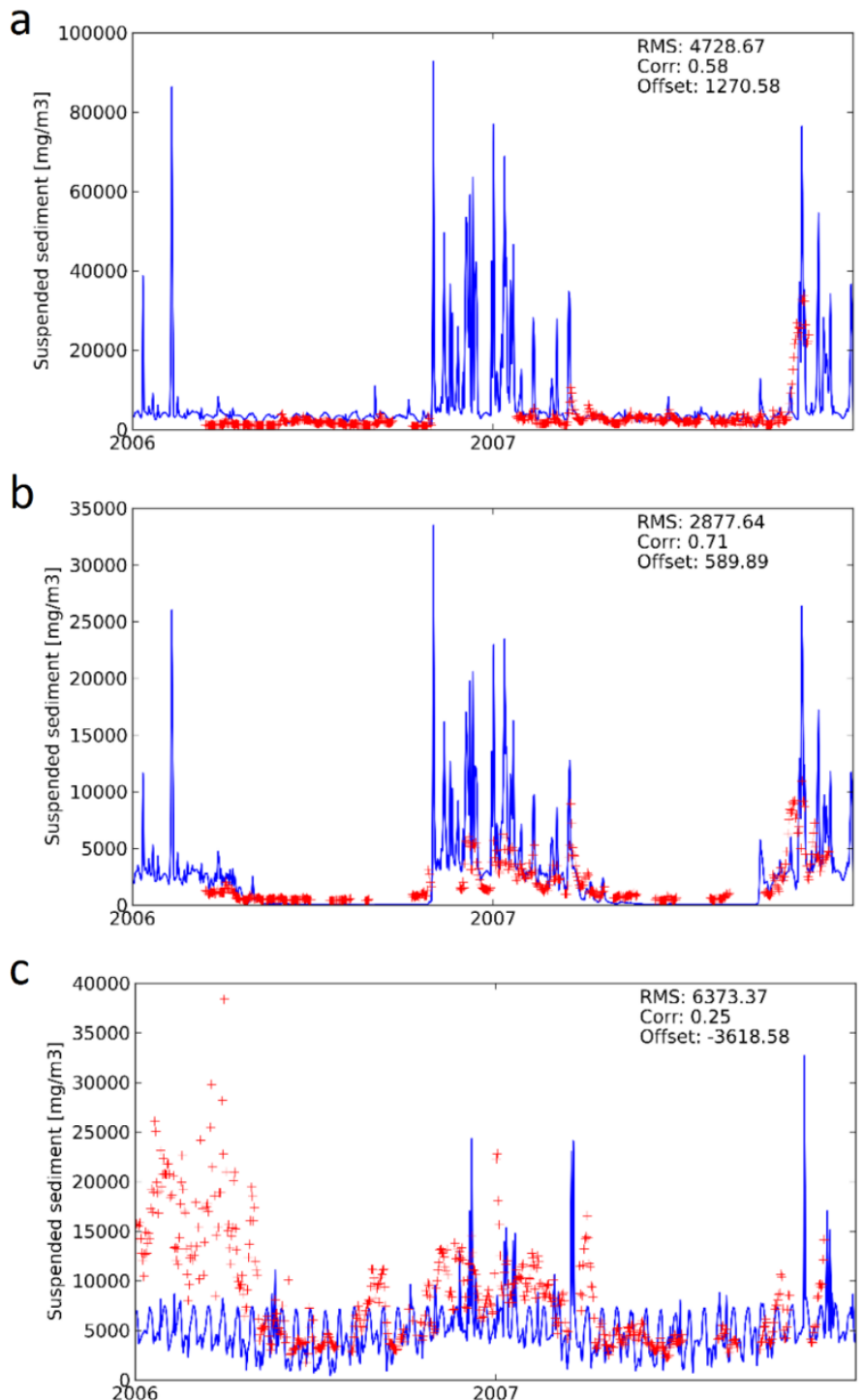

Figure 4. SPM concentrations for reference simulation. Line: 1D model, crosses: observations (SmartBuoy). Top: Oyster Grounds, $35 \mathrm{~m}$ depth; middle: Oyster Grounds, sea surface; bottom: West Gabbard, sea surface. 
a

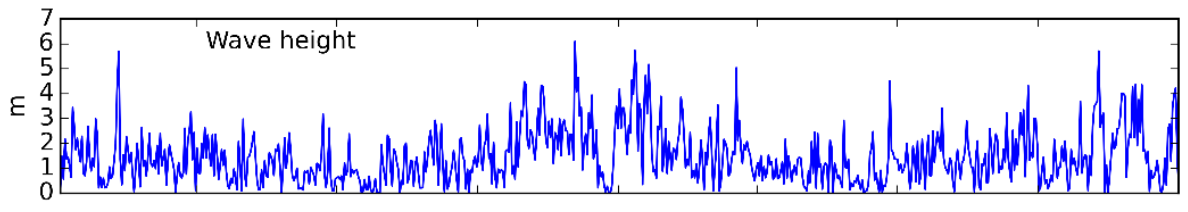

b

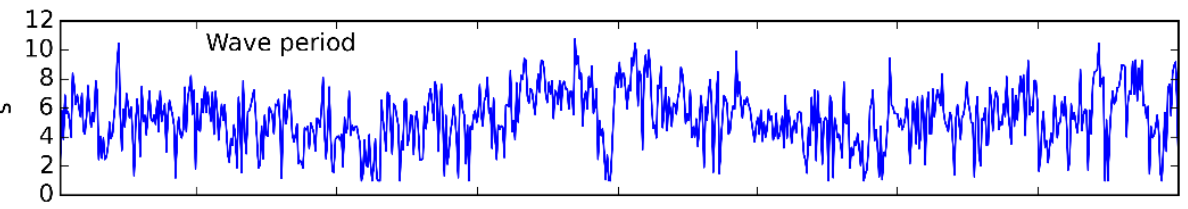

C

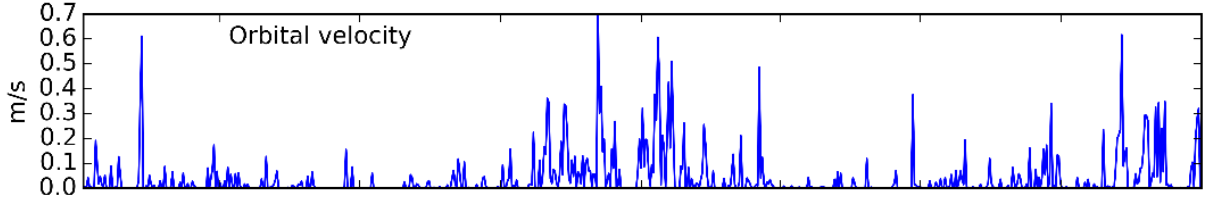

d
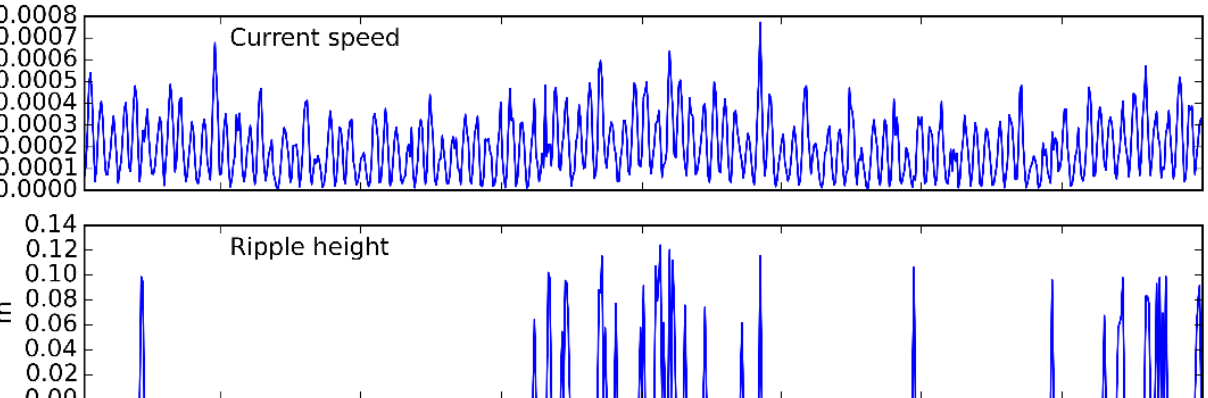

f
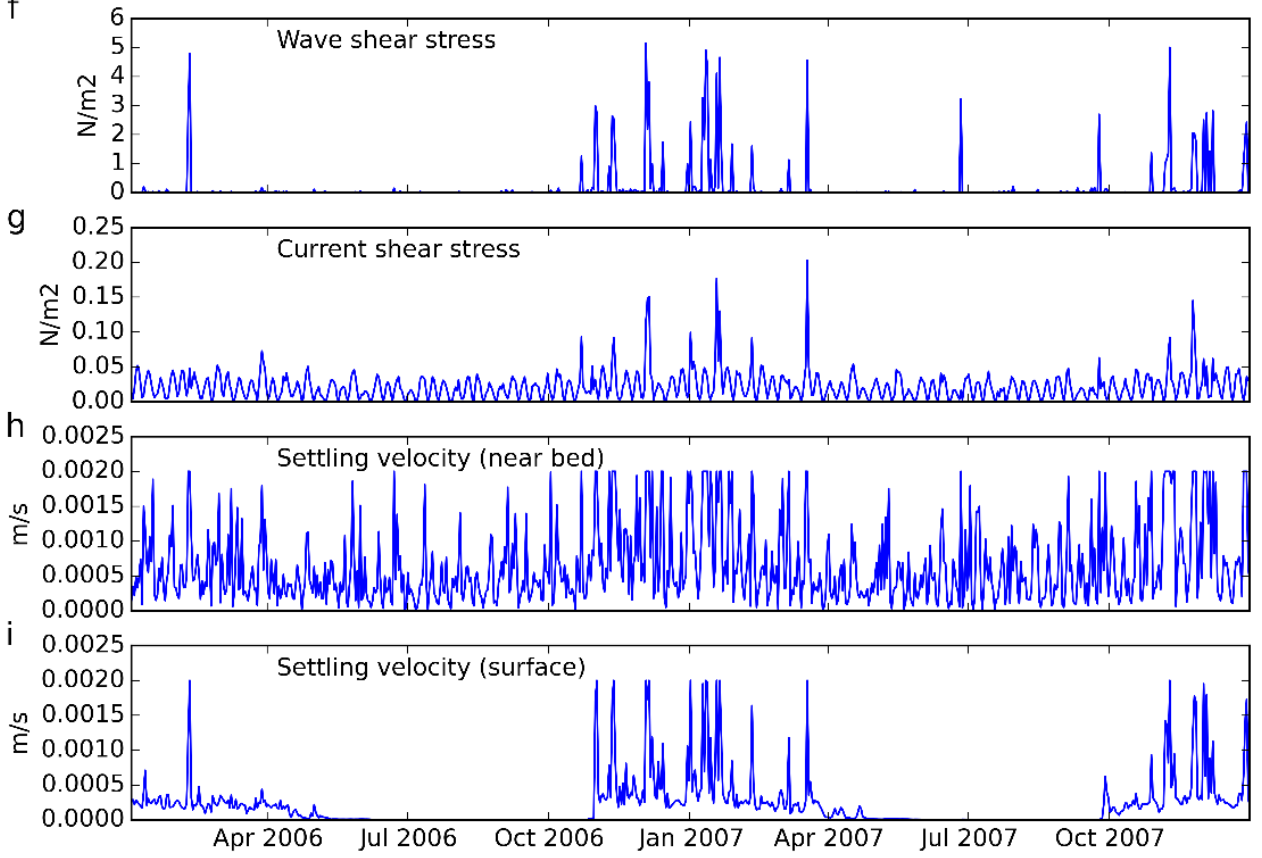

Figure 5. Processes contributing to the SPM concentrations at Oyster Grounds: a) significant wave height; b) zero crossing wave period; c) near-bed wave-driven orbital velocity; d) near-bed current speed; e) ripple height; f) wave-induced bed-shear stress; g) current-induced bed-shear stress; h) near-bed settling velocity; i) near-surface settling velocity. 
a

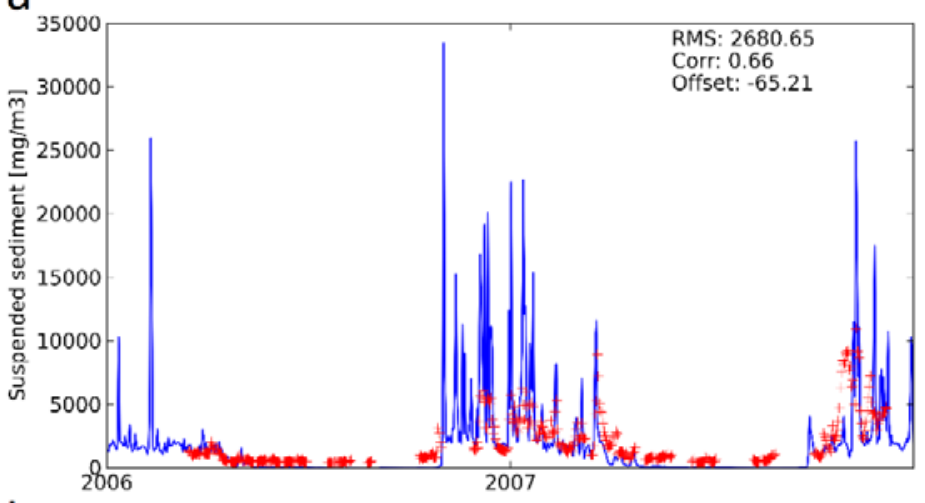

b

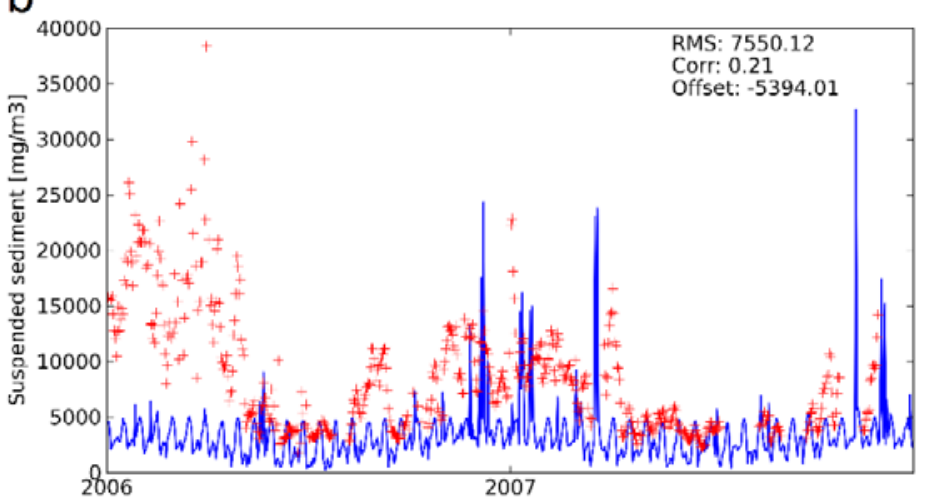

Figure 6. Surface SPM concentration at Oyster Grounds (top) and West Gabbard (bottom), $a=0.3$ in (26).

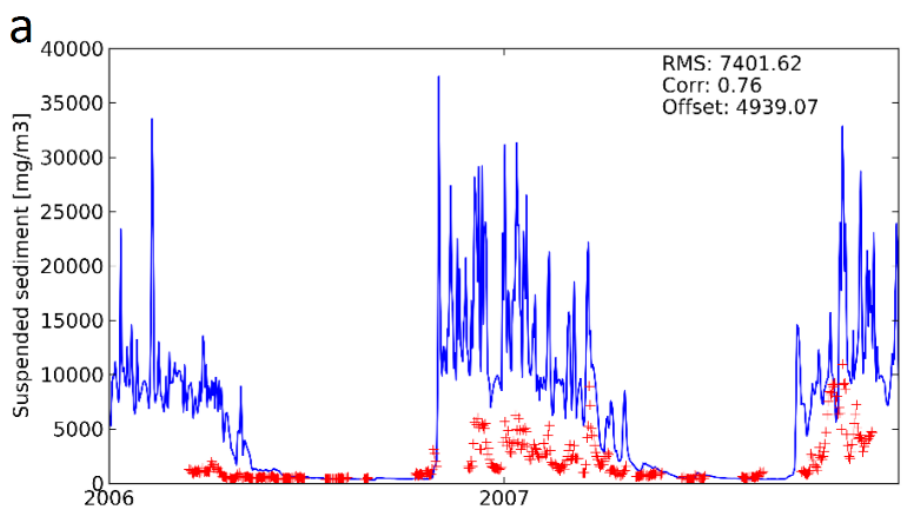

$b_{40}$

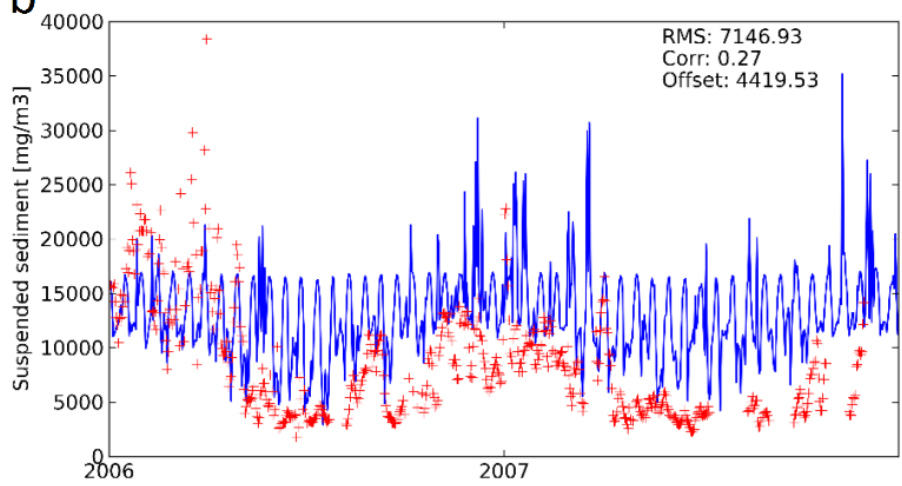

Figure 7. Surface SPM concentration at Oyster Grounds (top) and West Gabbard (bottom), $b=1.5$ in (26). 
a

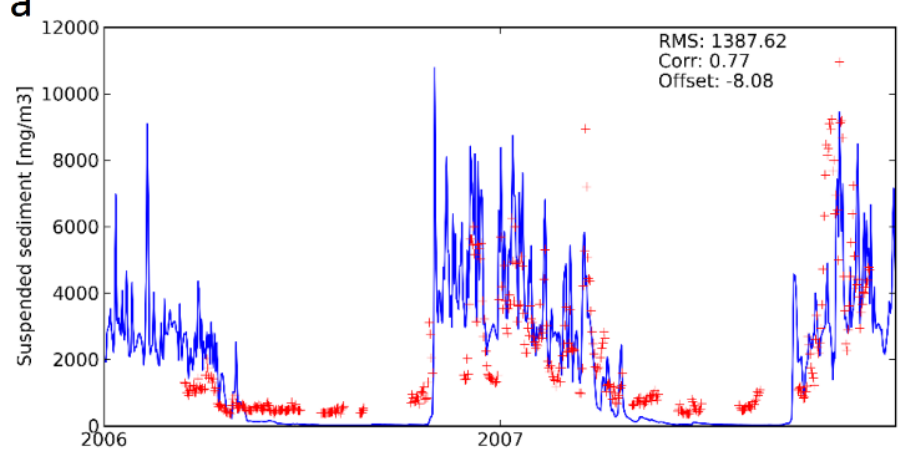

b

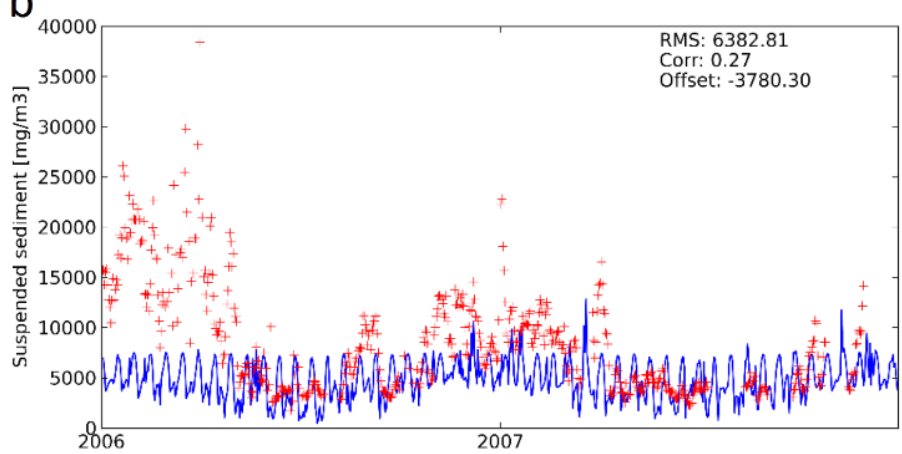

Figure 8. Surface SPM concentration at Oyster Grounds (top) and West Gabbard (bottom), $w_{s, \max }=0.01 \mathrm{~ms}^{-1}$.

Figure 9. Surface SPM concentrations at West Gabbard, double current ripple height (cf.

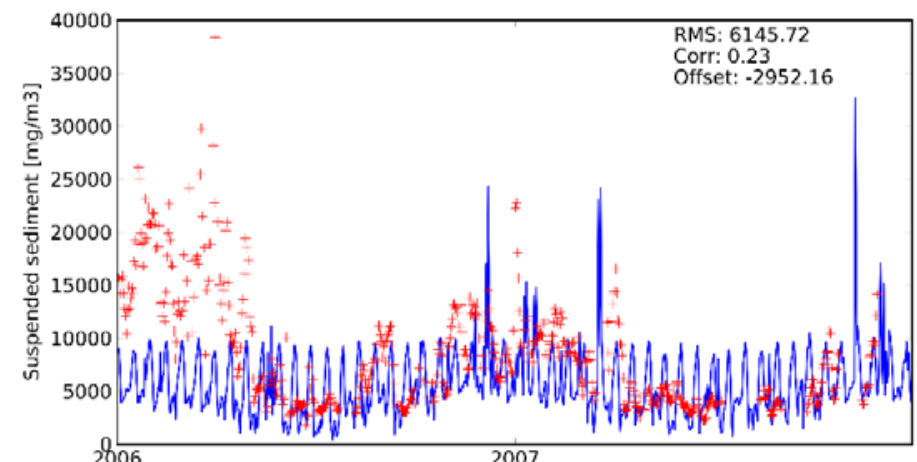

759

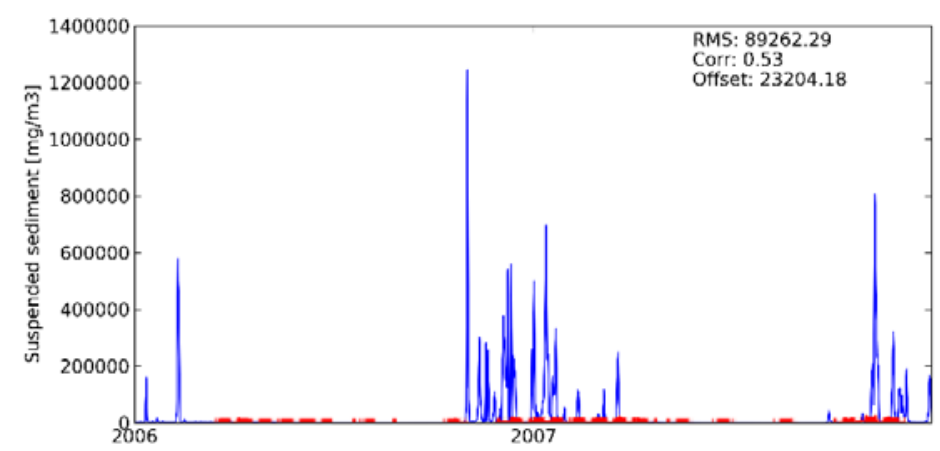

Figure 10. Surface SPM concentration at Oyster Grounds, no uptake limitation from sea bed (28). 


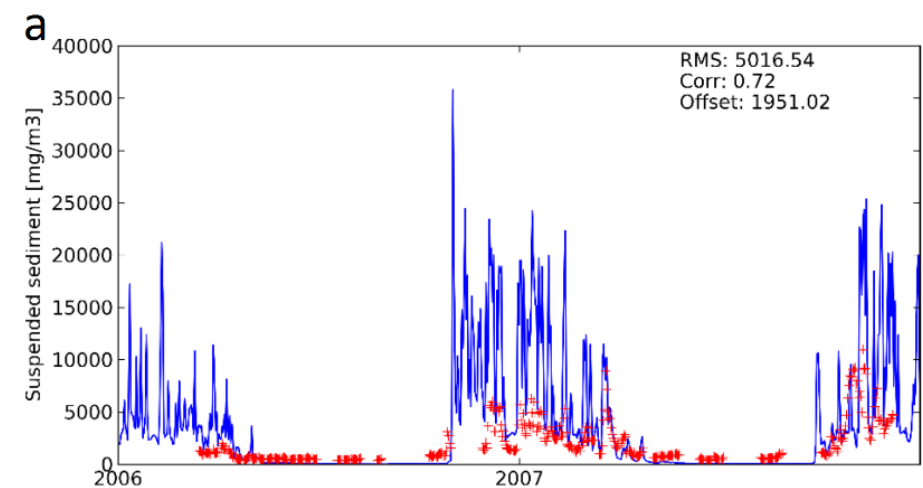

b

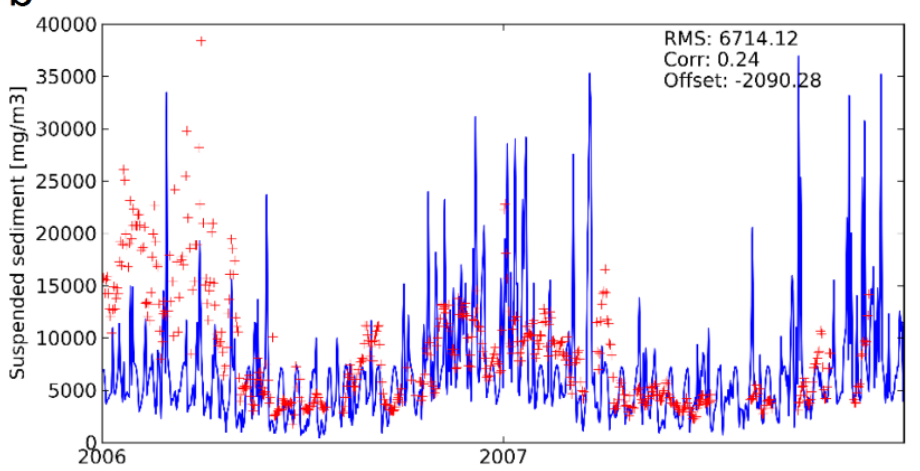

Figure 11. Surface SPM concentration at Oyster Grounds, double event-duration for wave generation $\left(t_{d, \max }=6 \mathrm{hr}\right)$.

767

a

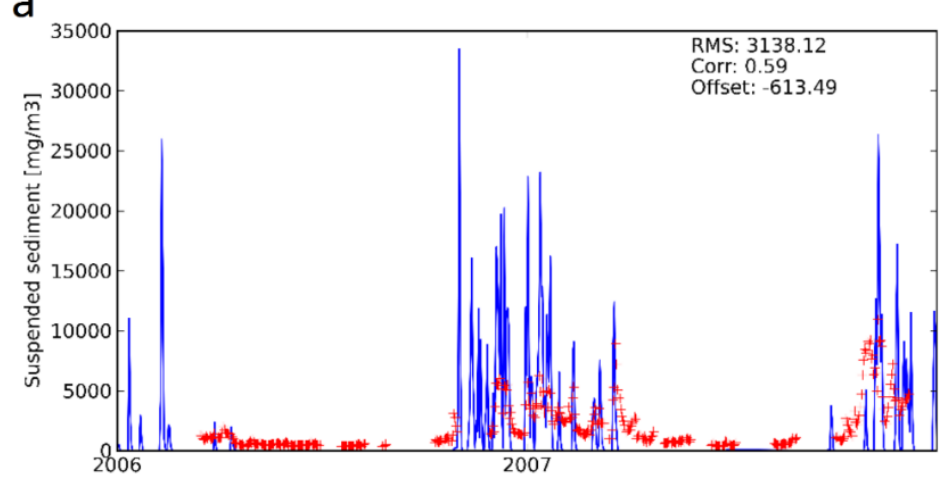

b

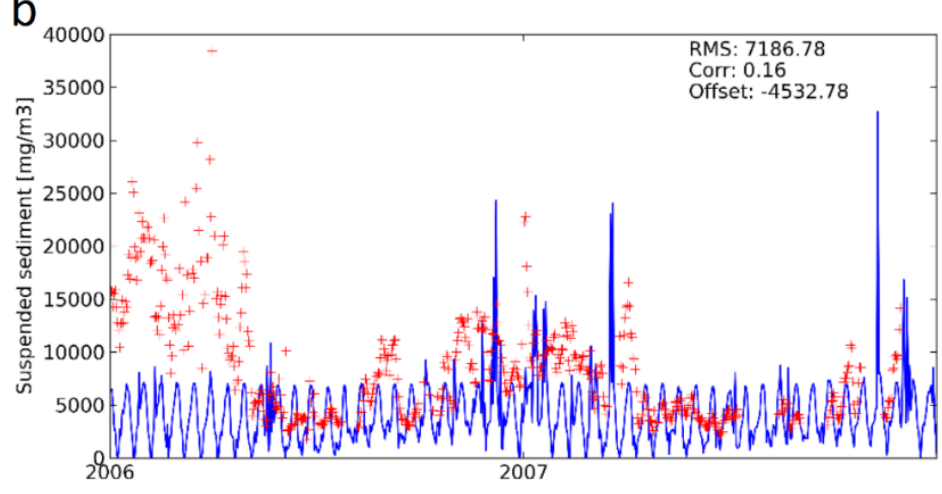

Figure 12. Surface SPM concentration at Oyster Grounds (top) and West Gabbard (bottom), $d_{\min }=0$ in (27). 


\section{a}

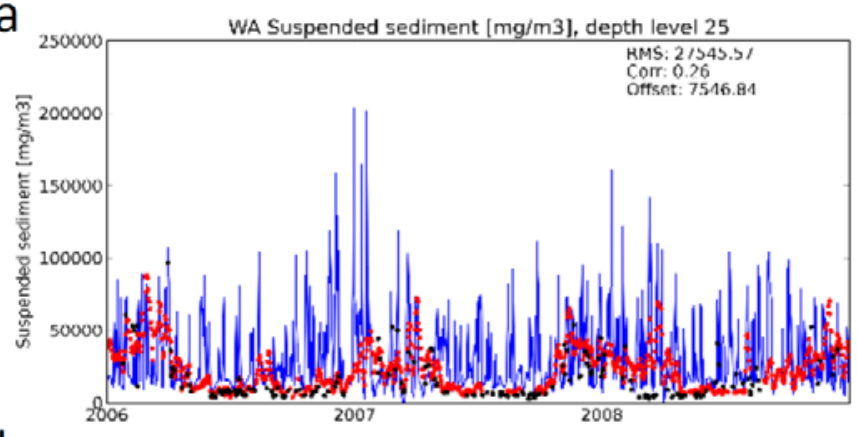

b

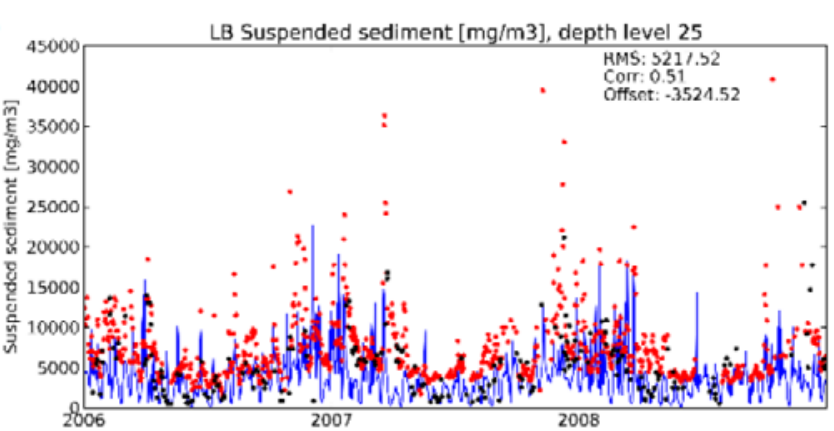

C

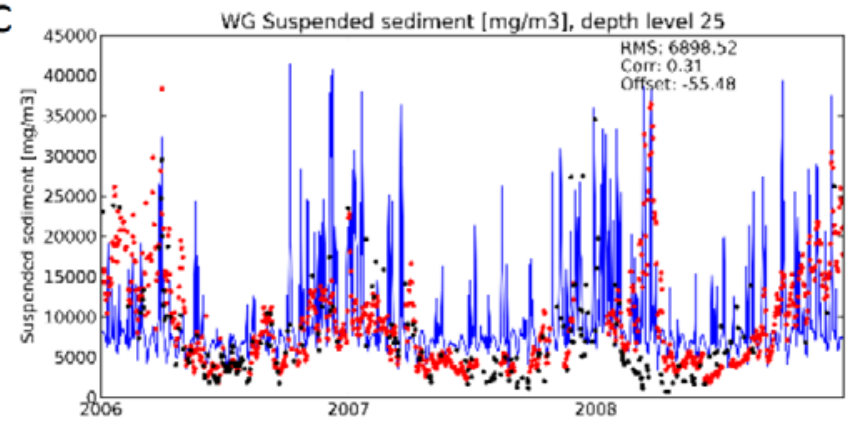

d

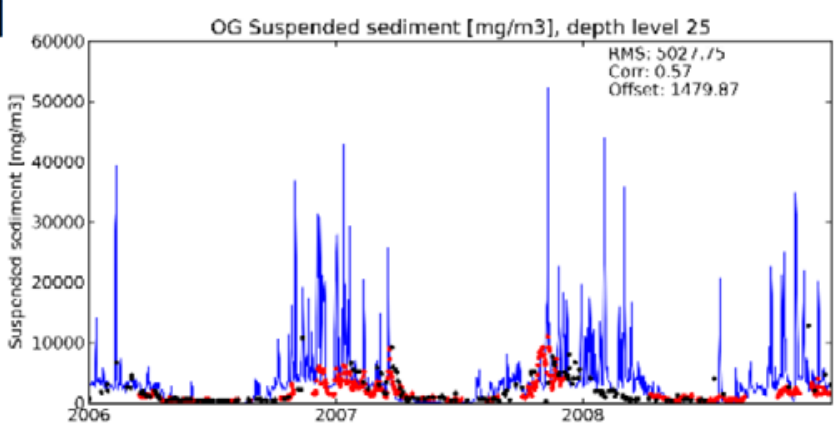

e ${ }_{25000} \quad$ ND Suspended sediment [mg/m3], depth level 25

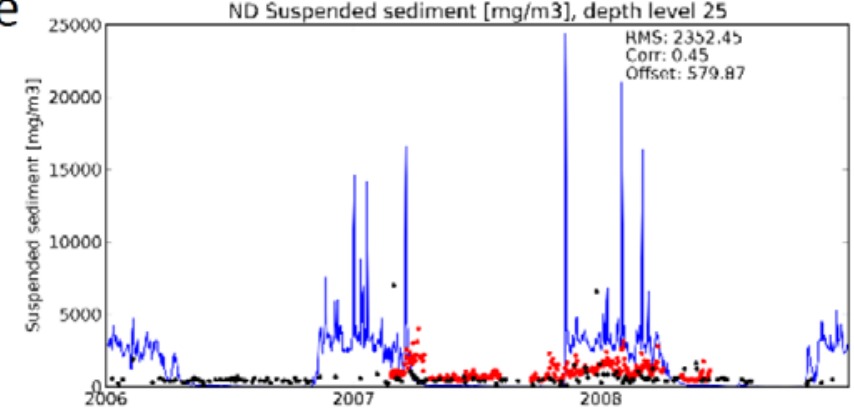

Figure 13. Surface SPM concentrations at SmartBuoy locations from the 3D model: a) Warp Anchorage; b) Liverpool Bay; c) West Gabbard; d) Oyster Grounds; e) North Dogger. Blue line: model results, red dots: SmartBuoy observations, black dots: satellite observations. 


\subsection{D: GETM-ERSEM-BFM}

779

Comparison of the SPM results of the northwest European continental shelf model with SmartBuoy observations at the 5 stations (Figure 13) showed an overall reasonable reproduction of the seasonal cycles in both timing and magnitude. For all stations except Liverpool Bay (Figure 13b), where values were generally underestimated by approximately a factor of 2, the high-frequency variability and peak values were over-estimated. At West Gabbard (Figure 13c), winter concentrations were much better represented than in the $1 \mathrm{D}$ model resulting in over-estimates of up to a factor of 2 for 2007, but still under-estimating concentrations for 2006 by up to a factor of 3 (Figure 4c), while summer concentrations were now above observed values by factors of $0-3$. These differences with the results of the $1 \mathrm{D}$ are most likely due to advection from near-by more shallow locations. The differences with the 1D model were smaller at the Oyster Grounds (Figure 13d, Figure 4b) which is located in a topographically more homogeneous area, where winter concentrations were now over-estimated by up to a factor of 5 , while summer concentrations were at observed levels. At the deepest site, North Dogger, non-peak winter concentrations were overestimated by a factor of about 2, while the very low summer concentrations were underestimated by near-zero modelled values (Figure 13e).

There was generally a good correspondence between the satellite observations and the SmartBuoy observations (Figure 13), indicating that the satellite observations can be used for comparison with the model results. Some exceptions were: i) a period in the late winter of 2007/2008, when the satellite observations at Warp Anchorage and West Gabbard did not pick up a strong resuspension event present in both the SmartBuoy observations and the model results; ii) Liverpool Bay, where summer concentrations according to the satellite were somewhat (a factor of 2-3) below the SmartBuoy observations, and iii) at the North Dogger site, where the satellite observations were mostly about half the SmartBuoy observations.

Comparing the composite maps for the winter of 2007/2008 (Figure 14), the true model mean (Figure 14a) gave up to about two times higher concentrations than the subsampled model mean (Figure 14c), suggesting that the satellite missed the higher resuspension events due to cloud cover. This is supported by the map of the number of satellite observations (Figure 14d), which implied less than 40 cloud-free days out of 182 in most of the domain. Comparing the subsampled model mean with the satellite mean (Figure 14c,b), together with the percentage difference between them (Figure 14e) indicates that the model produced a reasonable reflection of the high concentrations in shallow to the low concentrations in deep water. The low concentrations in deep water were over-estimated several times by the model, as were concentrations in the English Channel. The model over-estimated concentrations on the Dogger Bank by a factor of 2-3, and did not pick up the seaward end of Anglian Plume to the south and east of Dogger Bank, which was evident in the satellite average. The correlation coefficient (Figure 14f) was positive and between 0.2 and 0.8 in most of the domain, except off the shelf edge where concentrations were very low and negative correlations occurred. 
a

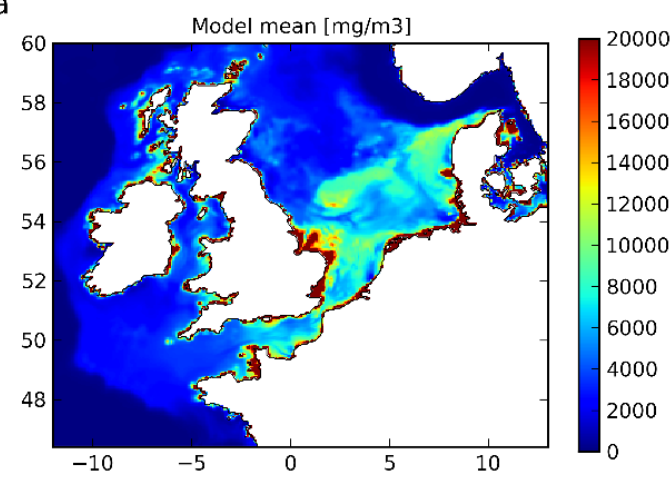

C

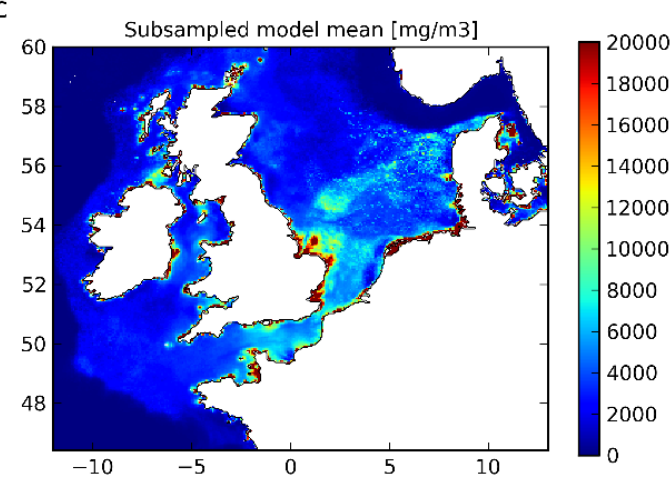

e

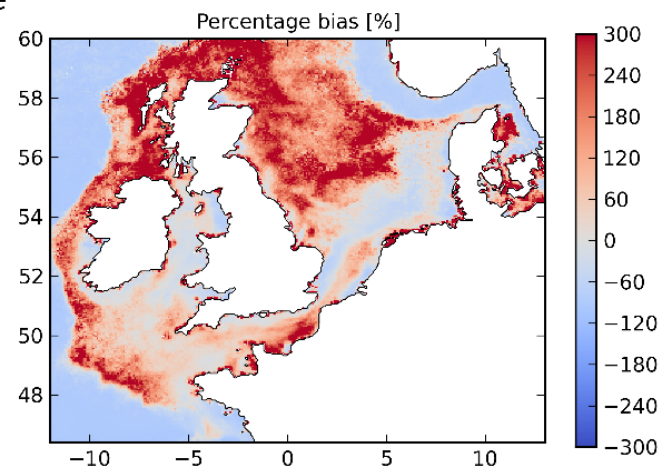

b

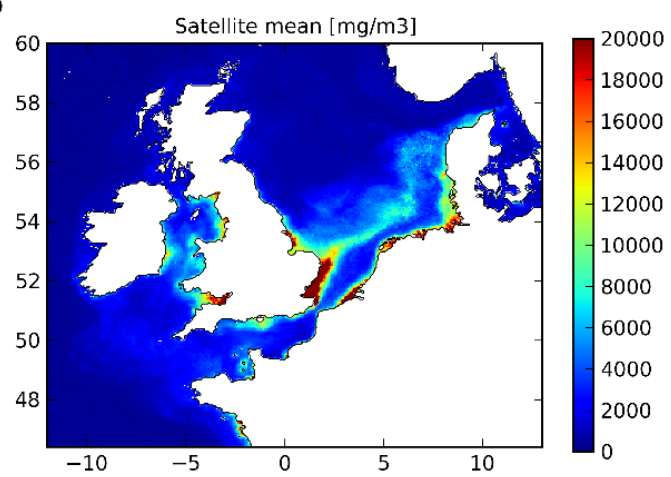

d

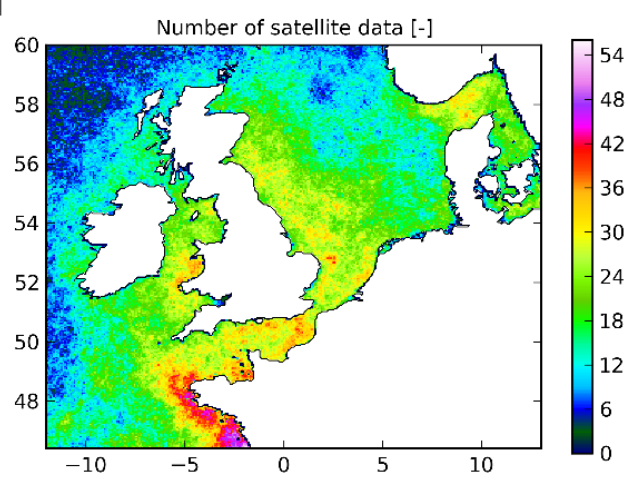

f

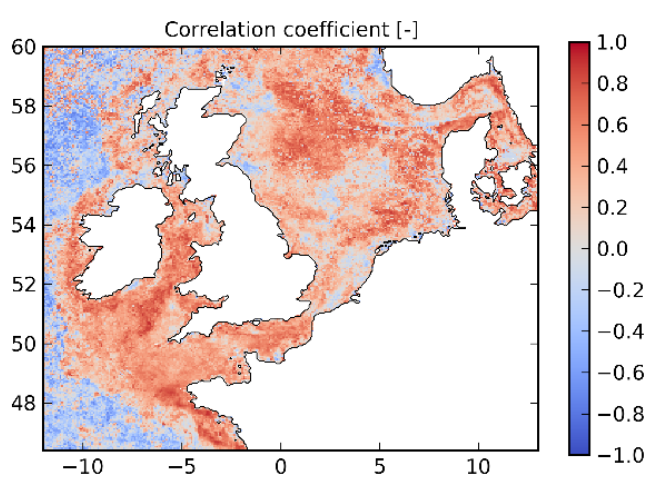

Figure 14. Comparison of modelled surface SPM concentrations with MODIS satellite data, October 2007 to March 2008 ('winter'). a) full model average; b) satellite average; c) sub-sampled model average; d) number of satellite observations; e) percentage bias; f) correlation coefficient.

The summer composites (Figure 15) suggested very similar values for the true and subsampled model means (Figure 15a,c), owing to an increased number of cloud-free days (Figure 15d), and more quiet conditions. The model over-estimated concentrations one to three times in shallow water and the English Channel, and under-estimated the low concentrations in the deeper, seasonally stratified waters by up to a factor of two. Again, the model did not pick up the seaward end of the Anglian Plume south of the Dogger Bank as evident in the satellite observations (Figure 15ac). Correlation coefficients ranged from 0.2 to more than 0.8 on most of the shelf, except in the deeper waters of the northern North Sea and the Atlantic shelf in the west, where correlations were very low or negative. 
a

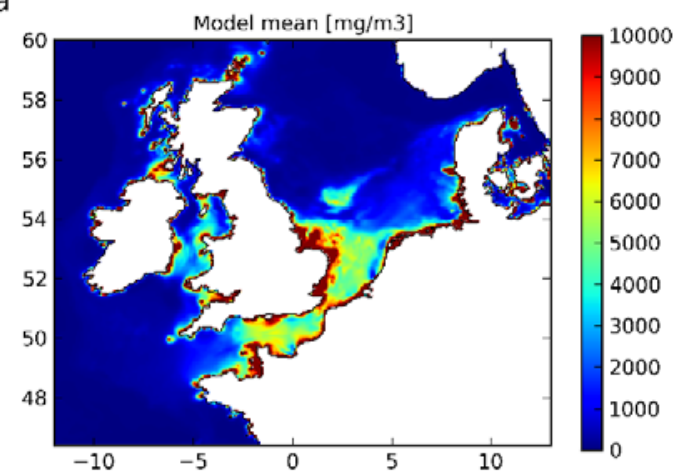

c

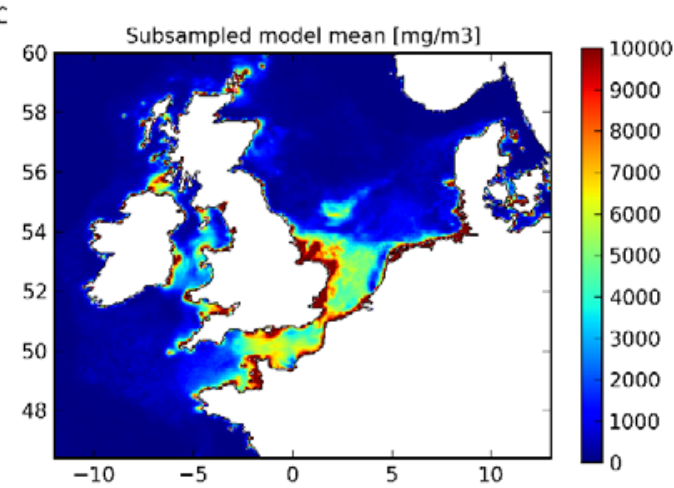

e

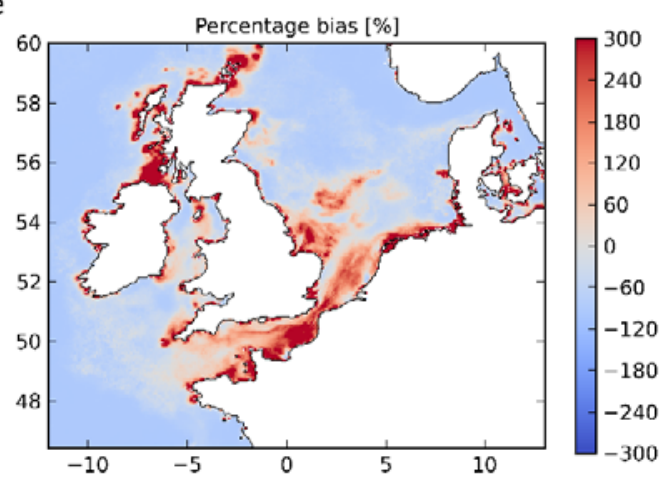

b

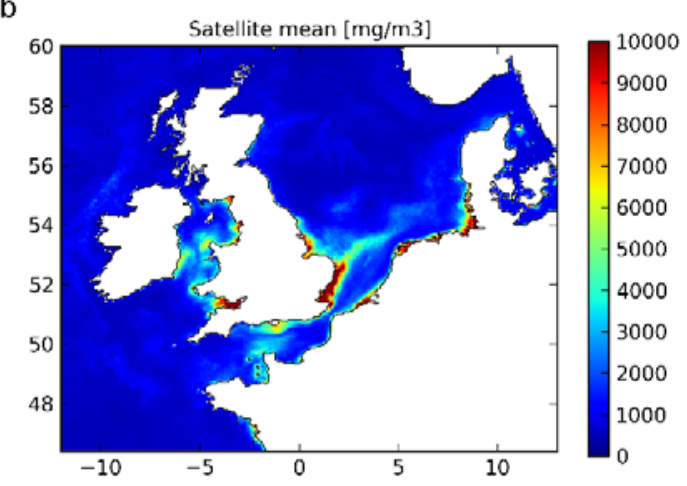

d

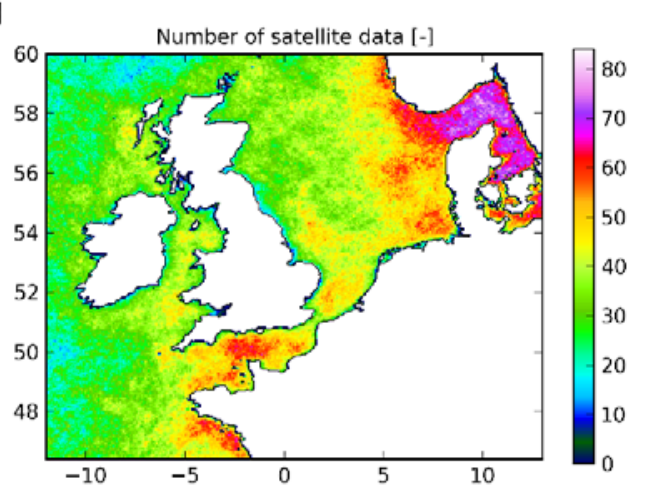

f

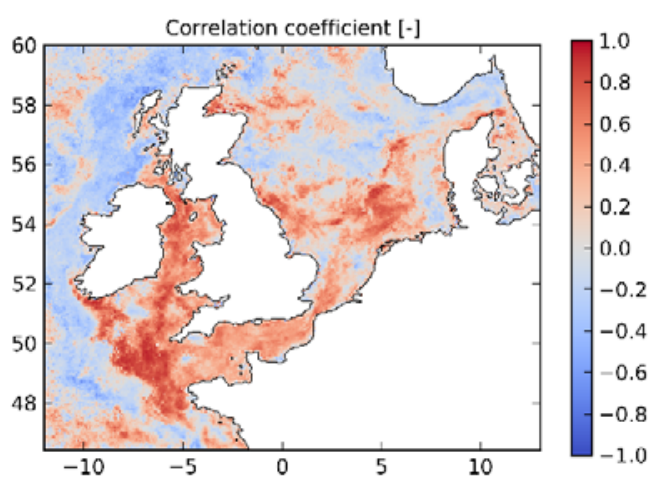

Figure 15. As Figure 14, but for April 2008 to September 2008 ('summer').

\section{Discussion and conclusions}

The SPM model reproduced the large-scale temporal features of observed time series of SPM concentrations reasonably well (typically well within a factor of 5 on an event scale) across a wide range of hydrodynamic conditions, as well as the large-scale spatial patterns on a seasonal basis (within a factor of 3). These are the first requirements for biogeochemical modelling in shelf seas, where phytoplankton are capable of integrating solar energy over several days. Inevitably, as with any model, deviations with observations were found and improvements could be made in future work, which were beyond the scope of the current project. These are discussed below.

The suspended sediment concentrations calculated by the model involve a wide range of inputs (bathymetry composed from a range of sources, estimated sea-bed composition, wind forcing from a global model, waves from a set of parameterisations, currents from a model), as well as a range of parameterisations with associated assumptions and parameter estimates/settings. Most of the latter were taken straight from the literature. Errors in all these components together are likely to contribute to the deviations between the model results and the observations. Within 
860

861

862

863

864

865

866

867

868

869

870

871

872

873

874

875

876

877

878

879

880

881

882

883

884

885

886

887

888

889

890

891

892

893

894

895

896

897

898

899

900

901

902

903

904

905

906

907

908

909

the context of a 3D model, and with limited observations, it is not possible to clearly separate these to suggest improvements, however we can indicate a few likely candidates.

The most notable deviation was the over-estimation of maximum SPM concentrations resulting from individual wind/wave events (the effects of which would be averaged out to some extent by the phytoplankton), predominantly during winter. This is probably related to a combination of the wave parameterisation and the balance between current and wave influence on resuspension in (14) (values of $c_{10}$ and $c_{11}$, which were taken here as given from literature). So potential candidates for further improvements would be re-calibration of (14), and a more sophisticated wave model (however, this would also have its local strengths and weaknesses, and come at additional computational cost).

The comparison with the satellite observations suggested that the model did not reproduce all of the features of the Anglian plume. This could be because: i) the plume may contain a high concentration of organic detritus which could be included in the satellite data (the biogeochemical model does produce a distinct detritus plume in this position); ii) the settling velocity at low concentrations could be too high; iii) the SPM in the plume settles and resuspends as it is transported (the model would need a module to dynamically change the composition of the sea bed to enable simulation of this process).

The sensitivity study with the 1D model setups was designed to demonstrate the effects and necessity of the parameterisations and controls in the model associated with the parameterisation of the concentration-dependent settling velocity. The results indicated that these were all required to achieve the presented model performance, and that the magnitude of the model responses were, in a varying degree, site-dependent. The sensitivity study suggested that more optimal settings could be found for individual sites, for instance, by finding a different balance between $a$ (26), $\mathrm{W}_{\mathrm{s}, \max }$ (26) and $t_{d, \max }(5)$. However, across a range of sites, the current settings are a good compromise, as was illustrated with the results of the 3D model. The 3D model was not used in the development of the SPM model or its calibration.

SPM sources (e.g., from rivers or coastal erosion) were not included here, but can easily be added to the 3D model without modifications to the SPM code. Without addition of a bottom pool that conserves SPM, the current model is not suitable for the calculation of SPM budgets, and will produce less reliable results in areas where the $\underline{\text { SPM concentration in the sea bed changes significantly with time. }}$

Other approaches for spatially resolved SPM modelling are possible. For instance, Gerritsen et al. (2000, 2001) used a single grain size in a 2D depth-averaged and a 3D approach with an erosion-rate formulation and riverine, coastal, open-boundary and sea-bed source terms calibrated through a fitting procedure to in situ and remote sensing SPM data. Their 2D approach used a fixed, spatially dependent settling velocity, again fitted to reproduce the observed SPM concentrations, whereas the 3D approach compared a fixed settling velocity with a power law formulation as used here, but to power 1 (i.e. linear in the concentration). Gayer et al., 2006 modelled SPM concentrations in the North Sea and Baltic Sea using three size fractions, a twolayered bed with an erosion-depth parameterisation related to the shear velocity and 


\begin{abstract}
910 within-bed diffusion related to bioturbation. They included cliff eriosion and fluvial
911 sources, and a sea-bed composition map based on a combination of multiple sources

912

913

914

915

916

917

918

919

920

921

922

923

924

925

926

927

928

929

930

931

932

933

934

935

936

937

and corrections using satellite imagery of SPM concentrations. Van Kessel at al., 2011 used two grain sizes and a sea-bed buffer composed of a sand layer and a fluff layer, combined with an erosion-rate approach, and tuned to a single SmartBuoy time series (Noordwijk). Ralston et al. (2012) considered four size fractions including one with a different settling velocity in fresh water to mimic flocculation, and studied the effects of interactions between bathymetry, stratification and fronts on the sediment dynamics in an estuary. They found, among others, trapping of sediment by fronts and pycnoclines, and effects of the density distribution on currents and bed-shear stresses which affected erosion and deposition.

Direct comparison of the skill of these models to reproduce spatial and temporal SPM concentrations is not possible based on the original publications because of the different data and methods used. Gerritsen et al. $(2000,2001)$ applied a goodness of fit criterion on zones and used this mainly to assess model sensitivity to parameter settings. Gayer et al. (2006) provided a visual comparison with satellite-derived concentrations for a single image, indicating broad-scale similarities, but substantial differences in detail. They also provided a time-series comparison for Helgoland, suggesting over-estimation by approximately a factor of two, and a slow response to events, in particular for settling. Van Kessel et al. (2011) compared results from a 1D and a 3D model with a 10-month time series, showing good correspondence for the 1D model, but a marked reduction in the fit for the 3D model, which did not pick up the high concentrations of individual resuspension events to the same extent. Ralston et al. (2012) provided comparison with a 9-day time series, suggesting reasonable prediction for low-salinity conditions, and under-estimation for higher salinity conditions. The substantial spatial differences evident in the more extensive validation presented here suggest that comparison with observations from single stations, or single satellite images may not be fully representative of overall model performance.
\end{abstract}

938

939

940

941

942

943

944

945

946

947

948

949

950

951

952

953

954

955

956

957

958

959

In conclusion, we have developed a 3D SPM model, specifically tailored to use in biogeochemical models, with the following features: i) it is computationally efficient, because of the single fraction used in combination with a, concentration-dependent settling velocity parameterisation; ii) it includes effects of waves through set of basic parameterisations, making it suitable to obtain first estimates for a wide range of hydrodynamic conditions at small computational cost; iii) it is implemented as a resuspension and settling mechanism, relying on the native advection and diffusion routines to calculate water-column concentrations. We have demonstrated that the model gives a reasonable reproduction of growing-season SPM concentrations across a wide range of hydrodynamical conditions in 1D water column model setups and in a 3 model setup, using both in-situ observations and remote sensing.

\title{
Acknowledgements
}

The development of the SPM model was funded by Cefas Seedcorn project DP261. The development of the north-west European shelf setup was funded by Cefas Seedcorn project DP315. Claire Coughlan, while at JRC (Ispra), created the openboundary forcing for temperature, salinity and nutrients. The SmartBuoy data were collected in projects A1228 and AE004 funded by Defra as part of the National Eutrophication Monitoring Programme. The SmartBuoy in Liverpool Bay forms a part of the Liverpool Bay Coastal Observatory (www.cobs.pol.ac.uk) coordinated by 
960 the Proudman Oceanographic Laboratory. ECMWF and BADC are thanked for 961 making the wind forcing available. Ifremer is thanked for processing the MODIS 962 satellite observations and making them available on their ftp server:

963 ftp.ifremer.fr.:/ifremer/cersat/products/gridded/ocean-color/atlantic. The authors thank

964 two anonymous reviewers for their substantial and constructive comments. 


\section{References}

Aldridge, J.N., Parker, E.R., Bricheno, L., Green, S.L., van der Molen, J., 2015. Assessment of the physical disturbance of the Northern European continental shelf seabed by waves and currents. Cont. Shelf Res., in press.

Apel, J.R., 1995. Principles of Ocean Physics. International Geophysics Series 38, Academic Press, London, 634 pp.

Baker, E.T., Lavelle, J.W., 1984. The effect of particle size on the light attenuation coefficient of natural suspensions. Journal of Geophysical Research 89, 8197-8203.

Balmaseda M.A,. K. Mogensen, A. Weaver, 2013. Evaluation of the ECMWF Ocean Reanalysis ORAS4. Q. J. R. Meteorol. Soc. 674, 1132-1161. DOI:10.1002/qj.2063

Baretta, J.W., W. Ebenhöh and P. Ruardij (1995), The European Regional Seas Ecosystem Model, a complex marine ecosystem model, Neth. J. Sea Res. 33, 233246.

Basford, D.J., Eleftheriou, A., Davies, I.M., Irion, G., Soltwedel, T., 1993. The ICES North Sea benthos survey: the sedimentary environment. ICES J. Mar. Sci. 50, 7180.

Bowers, D.G., Evans, D., Thomas, D.N., Ellis, K., Williams, P.J. le B., 2004. Interpreting the colour of an estuary. Estuarine, Coastal and Shelf Science 59, 1320.

Burchard, H., Bolding, K., 2002. GETM - a general estuarine transport model. Scientific documentation, Tech. Rep. EUR 20253 EN, European Commission.

Burchard, H., Bolding, K., Villareal, M.R., 1999. GOTM - a general ocean turbulence model. Theory, applications and test cases. Tech. Rep. EUR 18745 EN, European Commission.

Campbell, D.E., Spinrad, R.W., 1987. The relationship between light attenuation and particle characteristics in a turbid sea. Estuarine, coastal and shelf science 25, 5365.

Dobrynin, M., Gayer, G., Pleskachevsky, A., Günther, H., 2010. Effect of waves and currents on the dynamics and seasonal variations of suspended particulate matter in the North Sea. J. Mar. Sys. 82, 1-20.

European Centre for Medium-Range Weather Forecasts, 2006a. European Centre for Medium-Range Weather Forecasts (ECMWF) 40-year Re-Analysis (ERA-40) model data. NCAS British Atmospheric Data Centre, January 2015. http://catalogue.ceda.ac.uk/uuid/775634f7e339b5262067e28a5d7b679d

European Centre for Medium-Range Weather Forecasts, 2006b. Assimilated Data from the European Centre for Medium-Range Weather Forecasts (ECMWF) operational analysis program. NCAS British Atmospheric Data Centre, January 2015. http://catalogue.ceda.ac.uk/uuid/c46248046f6ce34fc7660a36d9b10a71

Eleveld, M.A., Pasterkamp, R., van der Woerd, H.J., Pietrzak, J.D., 2008. Remotely sensed seasonality in the spatial distribution of sea-surface suspended particulate matter in the southern North Sea. Est., Coast. Shelf Sci. 80, 103-113.

Feng, Y., Friedrichs, M., Wilkin, J., Tian, H., Yang, Q., Hofmann, E., Wiggert, J., and Hood, R., 2015. Chesapeake Bay nitrogen fluxes derived from a land-estuarine ocean biogeochemical modeling system: Model description, evaluation, and nitrogen budgets. J Geophys. Res., Biogeosciences 120, 1666-1695.

Gallegos, C.L., Correll, D.L., 1990. Modeling specral diffuse attenuation, absorption and scattering coefficients in a turbid estuary. Limnology and Oceanography 35, 1486-1502. 
1014

1015

1016

1017

1018

1019

1020

1021

1022

1023

1024

1025

1026

1027

1028

1029

1030

1031

1032

1033

1034

1035

1036

1037

1038

1039

1040

1041

1042

1043

1044

1045

1046

1047

1048

1049

1050

1051

1052

1053

1054

1055

1056

1057

1058

1059

1060

1061

1062

Gayer, G., Dick, S., Pleskachevsky, A., Rosenthal, W., 2006. Numerical modeling of suspended matter transport in the North Sea. Ocean Dynamics 56, 62-77. DOI 10.1007/s10236-006-0070-5

Gerritsen, H., Vos, R.J., van der Kaaij, Th., Lane, A., Boon, J.G., 2000. Suspended sediment modelling in a shelf sea (North Sea). Coastal Engineering 41, 317-352.

Gerritsen, H., Boon, J.G., van der Kaaij, T., Vos, R.J., 2001. Integrated modelling of suspended matter in the North Sea. Estuarine, Coastal and Shelf Science 53, 581594.

Gohin, F., Loyer, S., Lunven, M., Labry, C., Froidefond, J. M., Delmas, D., Huret, M., Herbland, A., 2005. Satellite-derived parameters for biological modelling in coastal waters: Illustration over the eastern continental shelf of the Bay of Biscay. Rem. Sens. Env. 95, 29-46.

Gohin, F., 2011. Annual cycles of chlorophyll-a, non-algal suspended particulate matter, and turbidity observed from space and in-situ in coastal waters. Ocean Sci. 7, 705-732

Grant, W.D., Madsen, O.S., 1982. Movable bed roughness in unsteady oscillatory flow. J. Geophys. Res. C (Oceans) 87, 469-481.

Green, M. O., Dolphin, T.J., Swales, A., Vincent, C.E., 1999. Transport of mixed-size sediments in a tidal channel, Coastal Sediments '99, Am. Soc. of Civ. Eng., Hauppauge, N. Y.

Greenwood, N., Parker, E.R., Fernand, L., Sivyer, D.B., Weston, K., Painting, S.J., Kröger, S., Forster, R.M., Lees, H.E., Mills, D.K., Laane, R.W.P.M., 2010. Detection of low bottom water oxygen concentrations in the North Sea; implications for monitoring and assessment of ecosystem health. Biogeosci 7, 1357-1373

Jerlov, N.G., 1976. Marine Optics. Elsevier, Amsterdam, 231 pp.

Lenhart, H.J., Mills, D.K., Baretta-Bekker, H., van Leeuwen, S.M., van der Molen, J., Baretta, J.W., Blaas, M., Desmit, X., Kühn, W., Lacroix, G., Los, H.J., Ménesguen, A., Neves, R., Proctor, R., Ruardij, P., Skogen, M.D., Vanhoutte-Grunier, A., Villars, M.T., Wakelin, S.L., 2010. Predicting the consequences of nutrient reduction on the eutrophication status of the North Sea. J. Mar. Sys. 81, 148-170.

Le Provost C., Lyard F., Genco M.L., Rabilloud F., 1988. A hydrodynamic ocean tide model improved by assimilation of a satellite altimeter-derived data set. J. Geophys. Res 103, C3, 5513-5529.

Mehta, A.J., 1989. On estuarine cohesive sediment suspension behavior. Journal of Geophysical Research 94 C10, 14303-14314.

Mills, D.K., Laane, R.W.P.M., Rees, J.M., Rutgers van der Loeff, M., Suylen, J.M., Pearce, D.J., Sivyer, D.B., Heins, C., Platt, K., Rawlinson, M., 2003. Smartbuoy: A marine environmental monitoring buoy with a difference, in Building the European capacity in Operational Oceanography, Proceedings of the 3rd International Conference on EuroGOOS, 3-6th December 2002, Athens, Elsevier Oceanography Series, 69, 311-316.

Mogensen, K., Alonso Balmaseda, M., Weaver, A., 2012. The NEMOVAR ocean data assimilation system as implemented in the ECMWF ocean analysis for System4. ECMWF Thechnical Memorandum 668, 59 pp.

OSPAR, 2010. Quality status report 2010. Ospar Commision, London, 176 pp., ISBN 978-1-907390-38-8, http://qsr2010.ospar.org.

Paramor, O.A.L., Allen, K.A., Aanesen, M., Armstrong, C., Hegland, T., Le Quesne, W., Piet, G.J., Raakær, J., Rogers, S., van Hal, R., van Hoof, L.J.W., van Overzee, 
H.M.J., Frid C.L.J., 2009. MEFEPO North Sea Atlas. University of Liverpool. ISBN 0906370604

Painting, S.J., Forster, R.M., 2013. Marine Ecosystem Connections: essential indicators of healthy, productive and biologically divers seas. Biogeochemistry 113, 1-7. DOI: 10.1007/s10533-013-9838-0.

Pingree, R.D., Holligan,P.M., Mardell, G.T., 1978. The effects of vertical stability on phytoplankton distributions in the summer on the northwest European Shelf. Deep Sea Res. 25, 1011-1028.

Portela, L.I., Ramos, S., Trigo-Teixeira, A., 2013. Effect of salinity on the settling velocity of fine sediments of a harbour basin. In: Conley, D.C., Masselink, G., Russell, P.E. and O’Hare, T.J. (eds.), Proceedings 12th International Coastal Symposium (Plymouth, England), Journal of Coastal Research, Special Issue No. 65, pp. 1188-1193, ISSN0749-0208.

Ralston, D.K., Geyer, W.R., Warner, J.C., 2012. Bathymetric controls on sediment transport in the Hudson River estuary: Lateral asymmetry and frontal trapping. Journal of Geophysical Research 117 C10013, DOI: 10.1029/2012JC008124.

Ruardij, P., van Haren, H., Ridderinkhof, H., 1997. The impact of thermal stratification on phytoplankton and nutrient dynamics in shelf seas: a model study. J. Sea Res. 38, 311-331.

Ruardij, P., van Raaphorst, W., 1995. Benthic nutrient regeneration in the ERSEMBFM ecosystem model of the North Sea. Neth. J. Sea Res. 33, 453-483.

Ruardij, P., Veldhuis, M.J.W., Brussaard, C.P.D., 2005. Modeling the bloom dynamics of the polymorphic phytoplankter Phaeocystis globosa: impact of grazers and viruses. Harmf. Alg. 4, 941-963.

Shields, A., 1936. Anwendung der Ähnlichkeits-Mechanik und der Turbulenzforschung auf die Geschiebebewegung. Preussische Versuchsanstalt für Wasserbau und Schiffbau, vol. 26, Berlin.

Shore Protection Manual, 1984. Vol I and II. US Army Corps of Engineers, Coastal Engineering Research Center, Vicksburg, Mississippi, USA, 656 pp.

Simpson, J.H., Burchard, H., Fisher, N.R., Rippeth, T.P., 2002. The semi-diurnal cycle of dissipation in a ROFI: model-measurement comparisons. Cont. Shelf Res. 22, 1615-1628.

Smith, J.D., McLean, S.R., 1977. Spatially averaged flow over a wavy surface. J. Geophys. Res. 82, 1735-1743.

Soulsby, R.L., 1995. Bed shear-stresses due to combined waves and currents, in: Stive, M.J.F., de Vriend, H.J., Fredsøe, J., Hamm, L., Soulsby, R.L., Teisson, C., Winterwerp, J.C. (Eds.), Advances in coastal morphodynamics. Delft Hydraulics, The Netherlands.

Soulsby, R.L., 1997. Dynamics of marine sands, 249 pp., Thomas Telford, London.

Soulsby, R.L., Whitehouse, R.J.S.W., 1997. Threshold of sediment motion in coastal environments. Proc. Pacific Coast and Ports '97 Conf., Christchurch, 1, University of Canterbury, New Zealand, 149-154.

Van der Molen, J., 2002. The influence of tides, wind and waves on the sand transport in the southern North Sea. Cont. Shelf Res., 22, 2739-2762.

Van der Molen, J., Aldridge, J.N., Coughlan, C., Parker, E.R., Stephens, D., Ruardij, P., 2013. Modelling marine ecosystem response to climate change and trawling in the North Sea. Biogeochem. 113, 213-236, DOI 10.1007/s10533-012-9763-7.

Van der Molen, J., Bolding, K., Greenwood, N., Mills, D.K., 2009. A 1-D vertical multiple grain size model of suspended particulate matter in combined currents and waves in shelf seas. J. Geophys. Res. 114, F01030, doi:10.1029/2008JF001150. 
Van der Molen, J., De Swart, H.E., 2001. Holocene wave conditions and waveinduced sand transport in the southern North Sea. Continental Shelf Research, 21, 1723-1749.

Van der Molen, J., Smith, H.C.M., Lepper, P., Limpenny, S., Rees, J., 2014. Predicting the large-scale consequences of offshore wind array development on a North Sea ecosystem. Cont. Shelf Res. 85, 60-72I 10.1016/j.csr.2014.05.018

Van der Molen, J., Ruardij, P., Greenwood, N., 2016. Potential environmental impact of tidal energy extraction in the Pentland Firth at large spatial scales: results of a biogeochemical model. Biogeoscienses 13, 2593-2609, doi:10.5194/bg-13-25932016.

Van Kessel, T., Winterwerp, H., van Prooijen, B., Van Ledden, M., Borst, W., 2011. Modelling the seasonal dynamics of SPM with a simple algorithm for the buffering of fines in a sandy seabed. Cont. Shelf Res. 31, 124-134.

Van Leussen, W., 1994. Estuarine macroflocs and their role in fine-grained sediment transport. Ph.D. thesis, Utrecht Univerity, Utrecht, The Netherlands.

van Leeuwen, S.M., Tett, P., Mills, D.K., van der Molen, J., 2015. Stratified and nonstratified areas in the North Sea: long-term variability and biological and policy implications. J. Geophys. Res. C (Oceans) 120, 4670-4686, DOI: 10.1002/2014JC010485.

Van Rijn, L.C., 1994. Principles of fluid flow and surface waves in rivers, estuaries, seas and oceans. Aqua Publications, Amsterdam, The Netherlands, 335 pp.

Verspecht, F., Rippeth, T.P., Howarth, M.J., Souza, A.J., Simpson, J.H., Burchard, H., 2009. Processes impacting on stratification in a region of freshwater influence: application to Liverpool Bay. J. Geophys. Res. C (Oceans) 114 C11022, DOI: 10.1029/2009JC005475.

Vichi M., Oddo, P., Zavatarelli, M., Coluccelli, A., Coppini, G., Celio, M., Fonda, S., Umani, Pinardi, N., 2003. Calibration and validation of a one-dimensional complex marine biogeochemical flux model in different areas of the northern Adriatic Sea. Annales Geophysicae 21, 413-436.

Vichi, M., Pinardi, N., Masina, S., 2007. A generalized model of pelagic biogeochemistry for the global ocean ecosystem. Part I: Theory. J. Mar. Syst. 64, 89-109.

Vichi, M., Ruardij, P., Baretta, J.W., 2004. Link or sink: a modelling interpretation of the open Baltic biogeochemistry. Biogeosci. 1, 79-100. SRef-ID: 17264189/bg/2004-1-79.

Voulgaris, G., Meyers, S.T., 2004. Temporal variability of hydrodynamics, sediment concentration and sediment settling velocity in a tidal creek. Continental Shelf Research 24, 1659-1683.

Wilson, K.C., 1989. Mobile-bed friction at high shear-stress. J. Hydraulics Div., ASCE, 115, 825-830.

$\underline{\mathrm{Xu}, \text { J., Hood, R.R., 2006. Modeling biogeochemical cycles in Chesapeake Bay with a }}$ coupled physical-biological model. Est., Coastal and Shelf Sci 69, 19-46. 